Article

\title{
Thiophene- and Carbazole-Substituted $N$-Methyl-Fulleropyrrolidine Acceptors in PffBT4T-2OD Based Solar Cells
}

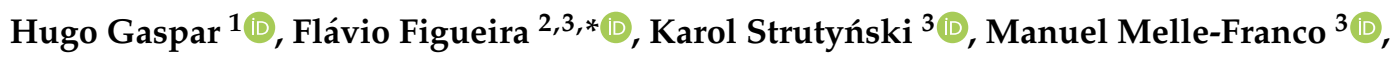 \\ Dzmitry Ivanou ${ }^{4}$, João P. C. Tomé ${ }^{2,5}$, Carlos M. Pereira ${ }^{6}\left(\mathbb{D}\right.$, Luiz Pereira ${ }^{7} \mathbb{D}$, Adélio Mendes ${ }^{4}{ }^{(\mathbb{D}}$, \\ Júlio C. Viana ${ }^{1}$ and Gabriel Bernardo ${ }^{4, * \mathbb{D}}$ \\ 1 IPC/i3N-Institute for Polymers and Composites, University of Minho, Campus de Azurém, \\ 4800-058 Guimarães, Portugal; hugo.da.silva.gaspar@gmail.com (H.G.); jcv@dep.uminho.pt (J.C.V.) \\ 2 QOPNA \& LAQV-REQUIMTE, Department of Chemistry, University of Aveiro, 3810-193 Aveiro, Portugal; \\ jtome@tecnico.ulisboa.pt \\ 3 CICECO_Aveiro Institute of Materials, Department of Chemistry, University of Aveiro, 3810-193 Aveiro, \\ Portugal; strutynski.karol@gmail.com (K.S.); manuelmelle.research@gmail.com (M.M.-F.) \\ 4 LEPABE, Department of Chemical Engineering, University of Porto, 4200-465 Porto, Portugal; \\ ivanou@fe.up.pt (D.I.); mendes@fe.up.pt (A.M.) \\ 5 CQE, Departamento de Engenharia Química, Instituto Superior Técnico, Universidade de Lisboa, \\ Av. Rovisco Pais, n1, 1049-001 Lisboa, Portugal \\ 6 Department of Chemistry, University of Porto, Rua do Campo Alegre, s/n, 4169-007 Porto, Portugal; \\ cmpereir@fc.up.pt \\ 7 Department of Physics and i3N-Institute for Nanostructures, Nanomodelling and Nanofabrication, \\ University of Aveiro, 3810-193 Aveiro, Portugal; luiz@ua.pt \\ * Correspondence: ffigueira@ua.pt (F.F.); gbernardo@fe.up.pt (G.B.)
}

Received: 7 February 2020; Accepted: 9 March 2020; Published: 11 March 2020

check for updates

\begin{abstract}
The impact of fullerene side chain functionalization with thiophene and carbazole groups on the device properties of bulk-heterojunction polymer:fullerene solar cells is discussed through a systematic investigation of material blends consisting of the conjugated polymer

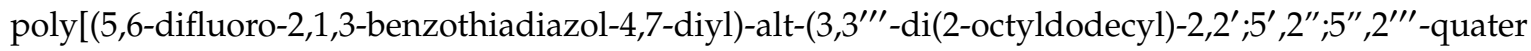
thiophen-5,5"'-diyl)] (PffBT4T-2OD) as donor and $\mathrm{C}_{60}$ or $\mathrm{C}_{70}$ fulleropyrrolidines as acceptors. The photovoltaic performance clearly depended on the molecular structure of the fulleropyrrolidine substituents although no direct correlation with the surface morphology of the photoactive layer, as determined by atomic force microscopy, could be established. Although some fulleropyrrolidines possess favorable lowest unoccupied molecular orbital levels, when compared to the standard $\mathrm{PC}_{71} \mathrm{BM}$, they originated OPV cells with inferior efficiencies than $\mathrm{PC}_{71} \mathrm{BM}$-based reference cells. Fulleropyrrolidines based on $\mathrm{C}_{60}$ produced, in general, better devices than those based on $\mathrm{C}_{70}$, and we attribute this observation to the detrimental effect of the structural and energetic disorder that is present in the regioisomer mixtures of $\mathrm{C}_{70}$-based fullerenes, but absent in the $\mathrm{C}_{60}$-based fullerenes. These results provide new additional knowledge on the effect of the fullerene functionalization on the efficiency of organic solar cells.
\end{abstract}

Keywords: polymer solar cells; fulleropyrrolidine acceptors; $\mathrm{C}_{70}$ mono-adducts; regioisomers; stereoisomers

\section{Introduction}

Organic photovoltaic (OPV) cells are a promising solar energy harvesting technology because of their flexibility, light weight, and compatibility with large-scale production using roll-to-roll methods 
(R2R) that are expected to reduce the module fabrication cost and the energy payback time [1-3]. Much effort has been made in the last two decades-focusing in the material design, device engineering, and morphology optimization-aiming to increase the power conversion efficiencies (PCE) of the OPV device. In the last few years, OPVs have developed significantly, attaining recently $P C E$ values $>16 \%$ for single junction devices [4-6] and $>17 \%$ for tandem cells [7].

The active layer in a OPV device is made of a blend of a p-type polymer and an n-type acceptor forming a bicontinuous interpenetrating network, known as bulk-heterojunction (BHJ). The p-type small band gap polymer poly[(5,6-difluoro-2,1,3-benzothiadiazol-4,7-diyl)-alt-(3,3'" -

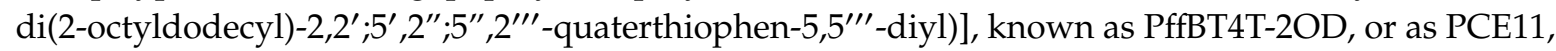
has recently become popular in the OPV field [8-15] due to its high hole mobility of 1.5-3.0 $\times 10^{-2}$ $\mathrm{cm}^{2} \mathrm{~V}^{-1} \mathrm{~s}^{-1}$ [10], associated with its high crystallinity, that allows its use in relatively thick $(\sim 300 \mathrm{~nm})$ and high efficiency solar cells. The n-type acceptors used in OPVs can be either fullerene derivatives or non-fullerene small molecules. Although the performance of OPVs using non-fullerene acceptors has already outperformed its fullerene-based counterpart, the research in polymer:fullerene solar cells using new 'non-standard' fullerenes remains very active [16-22].

Buckminsterfullerene $\mathrm{C}_{60}$ was the first fullerene used in an OPV device, in the seminal work by Sariciftci et al. [23] reporting the discovery of the photo-induced electron-transfer from a conducting polymer to $\mathrm{C}_{60}$. However, the very low solubility of $\mathrm{C}_{60}$ in common organic solvents makes it very difficult to process and therefore, soon after its introduction in the OPV field, the strategy of functionalizing $\mathrm{C}_{60}$ with solubilizing moieties was adopted. For this reason, the fullerenes (6,6)-Phenyl-C61-butyric acid methyl ester $\mathrm{PC}_{61} \mathrm{BM}[24,25]$ and its analogue (6,6)-Phenyl-C71-butyric acid methyl ester $\mathrm{PC}_{71} \mathrm{BM}$ [26] soon emerged as the two most widely used electron accepting materials in OPVs. These two fullerenes, $\mathrm{PC}_{61} \mathrm{BM}$ and $\mathrm{PC}_{71} \mathrm{BM}$, are now utilized as reference acceptors for all kinds of other fullerene acceptors, because of their good solubility, high electron mobility, and high chemical stability. A key difference between $\mathrm{PC}_{61} \mathrm{BM}$ and $\mathrm{PC}_{71} \mathrm{BM}$ is the broader photo-absorption profile of $\mathrm{PC}_{71} \mathrm{BM}$ in the visible region of the solar spectrum that allows increased photon harvesting and a potentially higher photocurrent for devices using $\mathrm{PC}_{71} \mathrm{BM}$ rather than $\mathrm{PC}_{61} \mathrm{BM}$, an important attribute that has brought the $\mathrm{C}_{70}$ analogue to the forefront of OPV research (despite its higher cost) $[27,28]$.

Fullerenes and derivatives display several physical and chemical properties that make them appealing for use in OPVs and other applications [29-31]. Fullerenes with proper organic moieties can be tuned on their solubility, highest occupied and lowest unoccupied molecular orbital (HOMO/LUMO) levels, orientation, and crystallinity in the solid state and on their surface energy, among others [32]. Several different fullerene functionalization strategies have been previously tested aiming to improve the performance of polymer:fullerene solar cells $[16,17,33]$. Some important examples of alternative fullerene acceptor families include dihydronaphthyl-based fullerenes [34-37] and fulleropyrrolidines [38-47].

Fulleropyrrolidines have several attractive features namely: they can be synthesized from pristine $C_{60}$ and $C_{70}$ in a simple one-step synthetic procedure using Prato reaction conditions [48]; ease of modification of the substituents bonded to the pyrrolidine ring by using as reactants commercially available or readily prepared glycine and aldehyde derivatives, and a good chemical stability. One of the first reports on the use of fulleropyrrolidine acceptors in OPVs, was made by Lee et al. [38] in 2007. These authors synthesized fulleropyrrolidine derivatives substituted with different chain lengths and tested them in OPVs with standard geometry and using the polymer MEH-PPV. The efficiencies obtained were all very low $(\leq 0.47 \%)$ and no comparison was made with reference devices using $\mathrm{PC}_{61} \mathrm{BM}$. Matsumoto et al. [39] synthesized and tested a series of fulleropyrrolidine derivatives in P3HT-based OPV cells with standard geometry. Several of the fulleropyrrolidine derivatives originated devices that outperformed reference devices with $\mathrm{PC}_{61} \mathrm{BM}$. The best fulleropyrrolidine-based devices attained a PCE of $3.44 \%$ compared to $2.53 \%$ for $\mathrm{PC}_{61} \mathrm{BM}$-based reference devices. A new phenothiazine-containing fulleropyrrolidine derivative was 
synthesized and tested by Mi et al. [40] in P3HT-based devices with standard geometry. However, the devices achieved the best modest efficiency of only $1.42 \%$. Saravanan et al. [41] synthesized two fullerene-terthiophene dyads without $\left(3 \mathrm{~T}-\mathrm{C}_{60}\right)$ and with $\left(3 \mathrm{TH}-\mathrm{C}_{60}\right)$ hexyl chains on the terthiophene substituent and tested them in P3HT devices with standard geometry. The 3TH-C60 fullerenes originated better devices (max PCE of $2.54 \%$ ) than 3T-C60 due to their higher miscibility with the P3HT matrix. Zhang et al. [42] synthesized two indole-containing fullerene derivatives and tested them in inverted solar cells with the structure of ITO/ZnO/P3HT:fullerene/ $\mathrm{MoO}_{3} / \mathrm{Ag}$. The best devices showed a PCE of $3.32 \%$, very similar to the PCE of $3.28 \%$ for similar reference $P C_{61} \mathrm{BM}$ based devices. Six novel soluble (60)fulleropyrrolidine derivatives were synthesized by Karakawa et al. [43] and tested in OPVs with P3HT and with PTB7. Devices with P3HT were made with the standard geometry ITO/PEDOT:PSS/BHJ/Al and devices with PTB7 were made with inverted geometry ITO/PFN/BHJ/MoOx/Al. The best P3HT-based devices using fulleropyrrolidine derivatives achieved a max. PCE of $2.41 \%$ comparable to the value of $2.30 \%$ obtained for reference P3HT devices with $\mathrm{PC}_{61} \mathrm{BM}$. Interestingly, the authors also observed that although the lowest unoccupied molecular orbital (LUMO) levels of all the fulleropyrrolidines closely resemble each other and those of $\mathrm{PC}_{61} \mathrm{BM}_{\text {, }}$ devices with P3HT displayed a large variety of PCEs ranging from $0.02 \%$ to $2.41 \%$ depending on the acceptor. In the case of PTB7-based devices using fulleropyrrolidines a max PCE of 7.34\% was achieved, slightly above the value of $7.03 \%$ obtained for reference PTB7 devices with PC ${ }_{61} B$. Kaunisto et al. [44] synthesized eight fulleropyrrolidine derivatives with thiophene substituents ranging from 1 to 4 thiophene units and tested them in inverted $\mathrm{BHJ}$ s using $\mathrm{P} 3 \mathrm{HT}$ as p-type material. Fulleropyrrolidine derivatives with one or two thiophene units performed better as acceptor materials than those with three or four thiophene units. Interestingly, even though all the devices with different fulleropyrrolidine derivatives exhibited very similar BHJ surface morphologies, as determined by atomic force microscopy (AFM), and all the fulleropyrrolidine derivatives exhibited very similar LUMO levels (either $-3.7 \mathrm{eV}$ or $-3.6 \mathrm{eV}$ ), as determined by cyclic voltammetry, the produced devices exhibited largely different $P C E$ ranging from $<0.01 \%$ to $2.0 \%$, and all of them inferior to the $P C E$ of reference P3HT:PC ${ }_{61}$ BM devices. Pitliya et al. [45] synthesized a novel fulleropyrrolidine derivative $\mathrm{C}_{60}$-fused N-(3methoxypropyl)-2-(carboxyethyl)-5-(4-cyanophenyl)fulleropyrrolidine (NCPF) and tested it in P3HT-based OPV devices with standard geometry ITO/PEDOT:PSS/BHJ/Al. Fulleropyrrolidine-based devices achieved a PCE of $1.77 \%$ comparable to $2.14 \%$ for reference devices based on $\mathrm{PC}_{61} \mathrm{BM}$. Eight fulleropyrrolidine derivatives with alternating $N$-phenyl or $N$-methyl group were synthesized by Liang et al. [46] and tested in P3HT-based OPVs with standard geometry ITO/PEDOT:PSS/BHJ/Ca/Al. The devices produced using different fulleropyrrolidine derivatives exhibited very different photovoltaic properties with PCEs ranging from $0.70 \%$ to $3.19 \%$, compared with the PCE value of $3.32 \%$ for reference devices with $\mathrm{PC}_{61} \mathrm{BM}$. Interestingly, even though some of the fullerenes exhibited more favorable LUMO levels than $\mathrm{PC}_{61} \mathrm{BM}$, they originated devices with considerably lower $V_{O C}$ and PCE values. Yamane et al. [47] synthesized two fulleropyrrolidine derivatives with the benzophenone moiety that can supress their crystallization and tested them in P3HT-based OPV devices with structure $\mathrm{ITO} / \mathrm{MoO}_{3} / \mathrm{BHJ} / \mathrm{Al}$. The devices exhibited higher thermal stability but lower PCE than reference devices with $\mathrm{PC}_{61} \mathrm{BM}$.

In this work, we synthesize eight novel thiophene- and carbazole-substituted $\mathrm{N}$-methyl-fulleropyrrolidine acceptors and test their impact on the performance of polymer solar cells based on the polymer PffBT4T-2OD. Although the final figures of merit are lower compared to similar OPVs with standard $\mathrm{PC}_{71} \mathrm{BM}$, the knowledge acquired on the influence of fulleropyrrolidine functionalization on the final device performances can open a new framework for the synthesis and use of such acceptors. 


\section{Materials and Methods}

\subsection{Materials}

The pristine fullerenes $C_{60}$ (>99.5\% purity) with $M_{w}=720.64$ g.mol ${ }^{-1}$ and $C_{70}$ (>99\% purity) with $M_{w}=840.77 \mathrm{~g} \cdot \mathrm{mol}^{-1}$, used in the synthesis of novel fullerene derivatives were purchased from Solenne $\mathrm{BV}$, as well as the $\mathrm{PC}_{61} \mathrm{BM}\left(M_{w}=910.88 \mathrm{~g} \cdot \mathrm{mol}^{-1}, 99 \%\right.$ purity $)$ used in cyclic voltammetry measurements.

The following materials, purchased from Ossila Ltd., were used in device fabrication: (i) Poly(3,4-ethylenedioxy-thiophene):poly(styrene sulfonic acid) (PEDOT:PSS, Heraeus Clevios AI4083); (ii) the polymer PffBT4T-2OD with $M_{n}=83,008 \mathrm{~g} \cdot \mathrm{mol}^{-1}$ and $M_{w}=172,033 \mathrm{~g} \cdot \mathrm{mol}^{-1}$ (catalogue \# M302); and (iii) the reference fullerene $\mathrm{PC}_{71} \mathrm{BM}$ (M113), with empirical formula $\mathrm{C}_{82} \mathrm{H}_{14} \mathrm{O}_{2}$ and $M_{w}=1030.99 \mathrm{~g} \mathrm{~mol}^{-1}$. The high purity grade solvent $o$-dichlorobenzene $(o$-DCB), purchased from Sigma-Aldrich, was used in device fabrication. All these materials and solvent were used as received without further purification.

\subsection{NMR Spectroscopy}

Bruker Avance 300 or 500 (300 or $500.13 \mathrm{MHz}$ for ${ }^{1} \mathrm{H}$ and $125.76 \mathrm{MHz}$ for ${ }^{13} \mathrm{C}$ ) spectrometers (Billerica, Massachusetts, EUA) were used to record the ${ }^{1} \mathrm{H}$ and ${ }^{13} \mathrm{C}$ solution NMR spectra of the functionalized fullerenes. The solvents used were $\mathrm{CS}_{2}$, deuterated acetone and deuterated chloroform (99.6\%, TCI Chemicals) and the internal reference was tetramethylsilane (TMS). The chemical shifts are expressed in (ppm).

\subsection{Preparation of Compounds $60 A-60 D$ and $70 A-70 D$}

A solution containing $100 \mathrm{mg}(0.14 \mathrm{mmol})$ of $\mathrm{C}_{60}$ or $\mathrm{C}_{70}, \mathrm{~N}$-methylglycine $(0.35 \mathrm{mmol})$ and of the corresponding aldehyde $(0.67 \mathrm{mmol})$ was stirred until reflux temperature. After this $0.67 \mathrm{mmol}$ of the corresponding aldehyde was added to the reaction every $3 \mathrm{~h}$ ( 3 times) and the reaction was maintained for $24 \mathrm{~h}$, then the solvent was removed in vacuum. The solid residue was purified by flash column chromatography (eluent: toluene/hexanes 1:3 with increasing amounts of toluene until purification of the first brown band) affording roughly $30-40 \%$ of the $N$-methyl-3,4-fulleropyrrolidine derivatives 60D and 70D. NMR spectra and characterization are shown in Supplementary Information (Figures S1-S24).

\subsection{Cyclic Voltammetry}

The electrochemical experiments were performed using an Autolab PGSTAT302N potentiostat. A three-electrode cell arrangement was used to record the voltammograms; a polished glassy-carbon (GC) pin (3 mm in diameter) was used as a working electrode, a platinum wire as a counter electrode, and a nonaqueous $\mathrm{Ag} \mid \mathrm{Ag}^{+}$reference electrode with an internal solution of $\mathrm{AgNO}_{3}(0.01 \mathrm{M})$ and $0.1 \mathrm{M}$ of $\mathrm{Bu}_{4} \mathrm{NPF}_{6}$ in acetonitrile. The fullerenes (ca. $0.6 \mathrm{mg} / \mathrm{mL}$ ) were dissolved in a solvent mixture of 4:1 (by volume) chlorobenzene (CB): acetonitrile and $0.1 \mathrm{MBu}_{4} \mathrm{NPF}_{6}$ was added as a supporting electrolyte. Before measurements, the solutions were deaerated by means of a 7 min purge with high purity Argon. A potential scan rate of $100 \mathrm{mV} / \mathrm{s}$ was used to record the cyclic voltammograms. The Argon flow was kept above the solution in the cell, throughout the measurements. All electrode potentials were quoted with respect to equilibrium potential $\left(E_{1 / 2}\right)$ of $\mathrm{Fc}+\mathrm{Fc}$ redox couple in the same solvent mixture; $E_{1 / 2}\left(\mathrm{Fc}^{+} / \mathrm{Fc}\right)=0.29 \mathrm{~V}$ vs. $\mathrm{Ag} \mid \mathrm{Ag}^{+}$. The LUMO and $\mathrm{HOMO}$ energy levels were estimated from the onset potential of the reduction $\left(E_{R e d}^{o n}\right)$ and oxidation $\left(E_{O x}^{o n}\right)$ respectively: $E_{L U M O}=-4.9-E_{R e d}^{o n}$; $E_{\text {HOMO }}=-4.9-E_{O x}^{O n}$.

\subsection{Ab Initio DFT Calculations}

We performed density functional theory calculations at the PBEh-3c level to compute all molecular structures [49]. The electronic structure energies reported were computed at the PBE-def2-TZVP level 
which has been found to show better accuracy than hybrid functionals for these systems [50-52]. For $C_{70}$ systems all isomers and diestereoisomers- $\alpha 1, \alpha 2, \beta 1$, and $\beta 2$-were explicitly computed. The ORCA 4.2 program was used to perform all the calculations [53].

\subsection{Absorption Spectroscopy}

Initially, the optical properties of the fulleropyrrolidines were characterized, in $o$-DCB solution, by means of UV-vis absorption spectroscopy. Due to the difficulty in preparing homogeneous spin-coated thin films of the fullerenes on quartz windows, we were unable to measure the UV-vis spectra of these. UV-vis absorption spectroscopy was later used to evaluate the effect of the prepared fulleropyrrolidines in the light absorption profiles of the different polymer:fullerene blends. Absorption spectra (UV-vis), of the blend thin solid-state films deposited in quartz substrates, were obtained on a Shimadzu UV-2501PC spectrophotometer, in the 350-800 $\mathrm{nm}$ range.

\subsection{Device Fabrication}

OPV devices were made with a standard structure ITO/PEDOT:PSS/Active layer/Ca/Al. ITO (Indium Tin Oxide) has a sheet resistance of $20 \Omega / \square$. Blend solutions of the polymer PffBT4T-2OD and the fullerene derivatives, with concentrations of respectively $4 \mathrm{mg} \cdot \mathrm{mL}^{-1}$ and $4.8 \mathrm{mg} \cdot \mathrm{mL}^{-1}(1: 1.2$ mass ratio) were prepared and then spin-coated on top of ITO substrates pre-coated with PEDOT:PSS. Other PffBT4T-2OD:fullerene mass ratios were also tested initially (1:3 and 3:1) but they produced lower device efficiencies. Contrary to previous work with PffBT4T-2OD using solvent mixtures of CB:o-DCB (1:1) to dissolve the polymer, here it proved necessary to use a pure $o$-DCB solvent (which has a stronger solvent power than the standard CB:o-DCB mixture) due to the high $M_{w}$ of the polymer used. Similarly to previous reports on fulleropyrrolidine based OPVs [42], no additives were used because preliminary tests have shown that they did not promote any improvements in efficiency. The blend solutions were pre-heated to $120^{\circ} \mathrm{C}$ and then they were spin-coated, in a nitrogen filled glove box and at a spin speed of $800 \mathrm{rpm}$, onto PEDOT:PSS/glass substrates that had been pre-heated to $120^{\circ} \mathrm{C}$. The as-deposited active layer films were then left drying inside the glove box for $1 \mathrm{~h}$. Finally, the top electrode-composed of $5 \mathrm{~nm}$ calcium and $100 \mathrm{~nm}$ aluminum-was evaporated sequentially on top of the active layer, under a pressure $<2 \times 10^{-6}$ mbar.

\subsection{Device Performance Characterization}

A Newport-Oriel 96000 AM 1.5 Global solar simulator, which had been calibrated using an NREL standard silicon solar cell to ensure an irradiance level of $1000 \mathrm{~W} / \mathrm{m}^{2}$, was used to measure the photovoltaic properties of the devices. An aperture mask (E521 from Ossila Ltd.) was used to limit the light-exposed area of the device to $2.6 \mathrm{~mm}^{2}$. All measurements were performed at room temperature.

\subsection{Atomic Force Microscopy (AFM)}

The surface morphology of the PffBT4T-2OD: fullerene thin films was imaged using atomic force microscopy (AFM) in tapping mode. AFM measurements were performed using a Molecular Imaging PicoLE AFM in contact mode and several scans were imaged in flattened mode data to remove the background slope. The scan size of topographic images was $5 \times 5 \mu \mathrm{m}$ in all experiments.

\section{Results and Discussion}

Several $\mathrm{C}_{60}$ and $\mathrm{C}_{70}$ fulleropyrrolidines were synthesized following the Prato methodology [48] where the appropriate azomethine ylide precursors are generated using $N$-methyl glycine (sarcosine) and the corresponding aldehyde, in this case thiophene and carbazole moieties (Figure 1). 

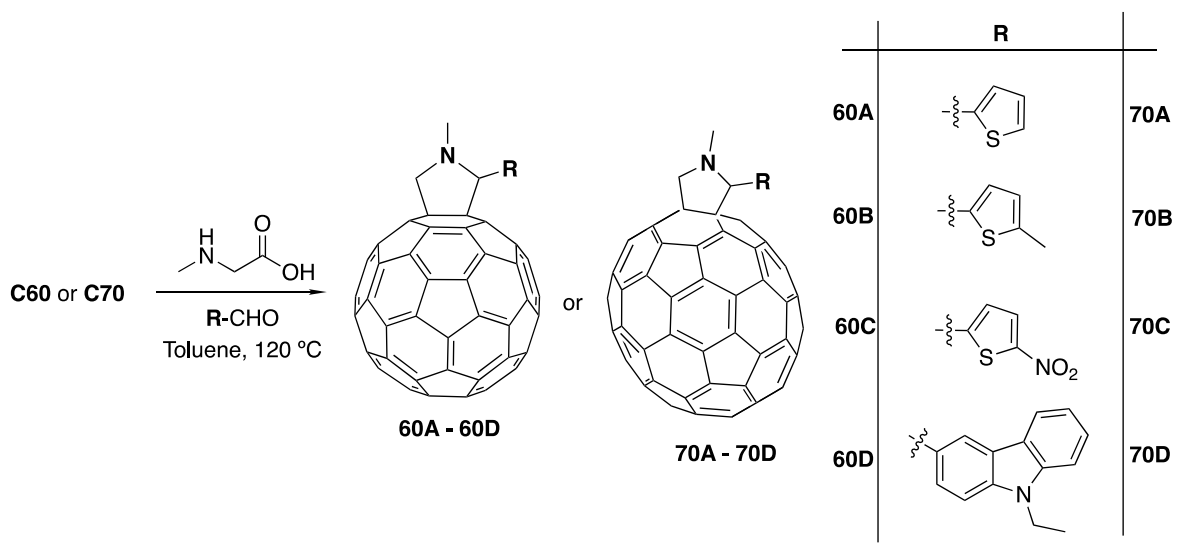

Figure 1. Synthetic method used in the preparation of compounds $60 \mathrm{~A}$ to $60 \mathrm{D}$ and $70 \mathrm{~A}$ to $70 \mathrm{D}$.

These precursors react readily with $\mathrm{C}_{60}$ and $\mathrm{C}_{70}$ providing fulleropyrrolidines containing substituted thiophene and carbazole moieties. Herein, this was achieved by a controlled cycloaddition reaction in which a pyrrolidine ring is fused with a $(6,6)$ ring junction of both $C_{60}$ or $C_{70}$.

Fulleropyrrolidines $60 \mathrm{~A}$ to $60 \mathrm{D}$ were synthesized using the 1,3-dipolar cycloaddition of the corresponding thiophene and carbazole aldehydes and $\mathrm{C}_{60}$, with $\mathrm{N}$-methylglycine and paraformaldehyde in toluene under reflux. After purification by column chromatography on silica gel compounds 60A to 60D were obtained in around $40 \%$ yield. 70A to 70D were prepared in the same manner replacing $\mathrm{C}_{60}$ with $\mathrm{C}_{70}$. The final structures were confirmed by ${ }^{1} \mathrm{H} \mathrm{NMR}$ with spectroscopy assignments supported by $2 \mathrm{D}-\mathrm{H}$ experiments.

It is possible to note that the solubility of the resulting $C_{70}$ derivatives was improved when compared with the solubility of the substituted $\mathrm{C}_{60}$. This became particularly evident when preparing concentrated fullerene solutions $\left(\sim 20 \mathrm{mg} \cdot \mathrm{mL}^{-1}\right)$ for ${ }^{13} \mathrm{C}$ NMR analysis-while all the $C_{70}$ derivatives were soluble or partially soluble in deuterated chloroform $\mathrm{CDCl}_{3}\left(\mathrm{C}_{70}\right.$ bearing the carbazole unit showed to be a little less soluble), the $\mathrm{C}_{60}$ derivatives were not soluble in $\mathrm{CDCl}_{3}$, and could be completely solubilized only in $\mathrm{CS}_{2}$ (the most powerful solvent for fullerenes). This higher solubility of $C_{70}$ derivatives in organic solvents, compared to the corresponding $C_{60}$ derivatives, has been previously reported $[54,55]$. The ${ }^{1} \mathrm{H}$ NMR spectra of the $\mathrm{C}_{60}$ derivatives are quite simple and shows the characteristic features of a $N$-methyl-(60)fulleropyrrolidine mono-adducts. The ${ }^{1} \mathrm{H}$ NMR spectra of the $\mathrm{C}_{70}$ derivatives exhibited four singlets and four sets of doublets $(J \approx 9.5 \mathrm{~Hz})$ for the pyrrolidine protons, demonstrating the presence of four different isomeric products of $C_{70}$ mono-adducts $(\alpha 1$, $\alpha 2, \beta 1$, and $\beta 2$, as represented in Figure S25). Unlike $C_{60}$, in which all carbon atoms and double bonds are initially equivalent, the lower symmetry of $C_{70}$ gives rise to an array of different reactivities. Integration of spectra based on the pyrrolidine protons allowed us to estimate the fractions of each isomer (Table 1).

Table 1. Estimation in percentage of the fraction of isomers present in $C_{70}$ derivatives.

\begin{tabular}{ccccc}
\hline & $\alpha \mathbf{1}(\mathbf{\%})$ & $\boldsymbol{\alpha 2}(\mathbf{\%})$ & $\boldsymbol{\beta 1}(\mathbf{\%})$ & $\boldsymbol{\beta 2} \mathbf{( \% )}$ \\
\hline 70A & 30 & 20 & 25 & 24 \\
70B & 30 & 27 & 25 & 17 \\
70C & 47 & 18 & 20 & 18 \\
70D & $*$ & $*$ & $*$ & $*$ \\
\hline \multicolumn{5}{c}{ * NMR is too complex to make a correct estimation }
\end{tabular}

The cyclic voltammograms of the eight synthesized fulleropyrrolidine acceptors, as well as the voltammograms of the corresponding $\mathrm{PC}_{61} \mathrm{BM}$ and $\mathrm{PC}_{71} \mathrm{BM}$ references are shown in Figure $2 \mathrm{a}$. The corresponding HOMO/LUMO levels determined from these voltammograms are shown in Table 
$\mathrm{S} 1$ in Supplementary Information and represented in Figure $2 b$. Also represented in Figure $2 b$ are the HOMO/LUMO levels of the polymer, from the literature [10]. The HOMO/LUMO levels that we have determined for $\mathrm{PC}_{61} \mathrm{BM}$ and $\mathrm{PC}_{71} \mathrm{BM}$ are in excellent agreement with literature [56,57] which attests the reliability of our measurements for the fulleropyrrolidine acceptors. The fulleropyrrolidines $60 \mathrm{~A}$, 60B, 70A, and 70B have slightly higher LUMO levels than the PC ${ }_{71} \mathrm{BM}$ standard which should favor higher $V_{O C}$ and PCE values assuming that all other factors remain unchanged.

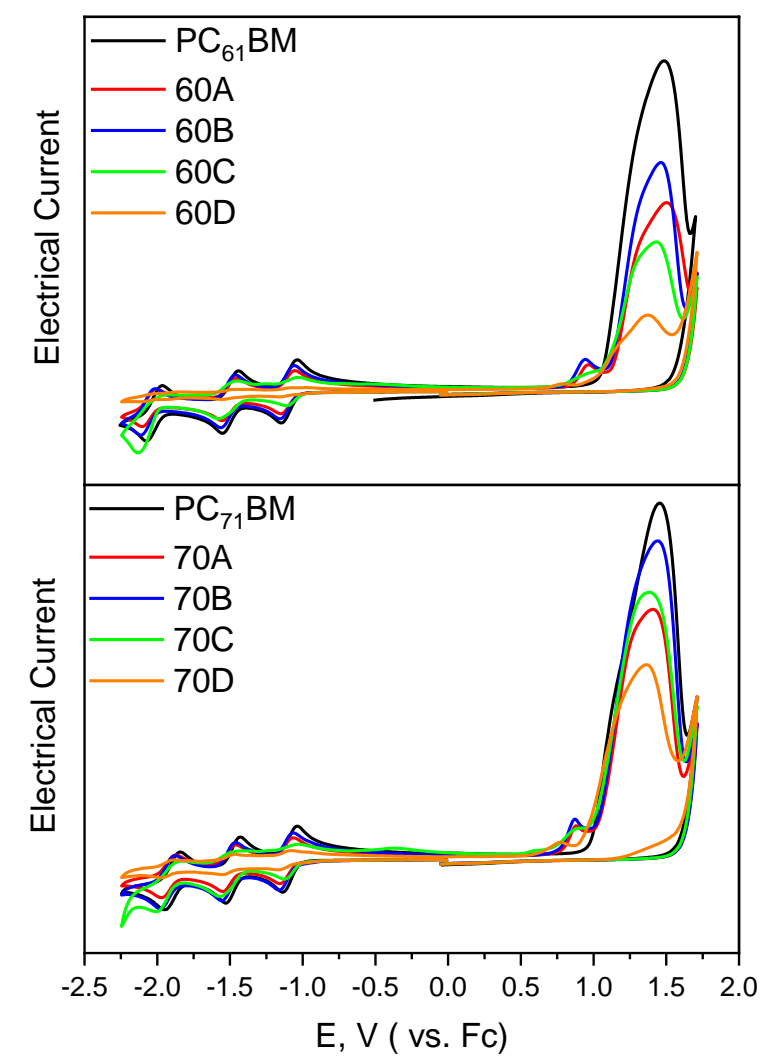

(a)

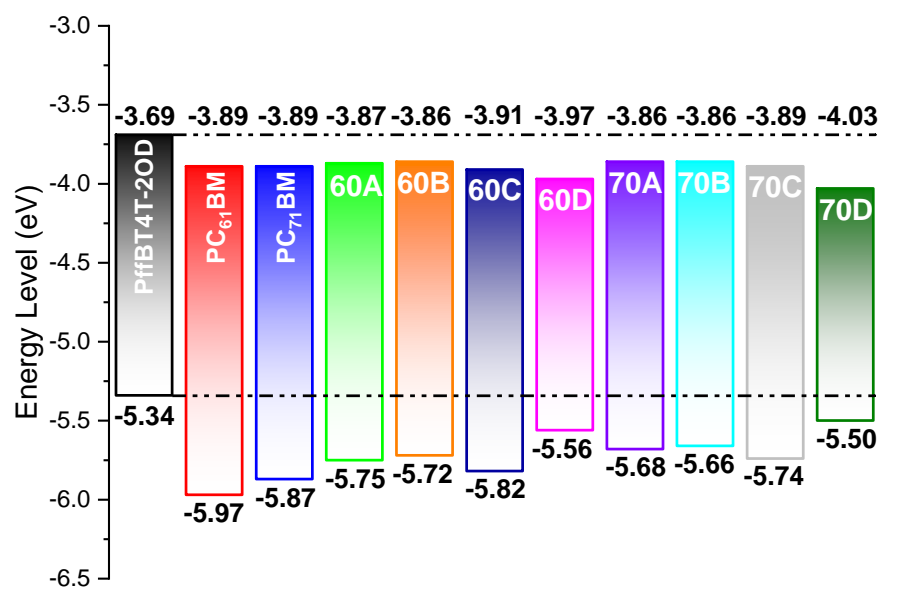

(b)

Figure 2. (a) Cyclic voltammetry results for all different fullerenes. The electrical current scale is shifted arbitrarily for clarity. (b) HOMO and LUMO levels for all materials as calculated from cyclic voltammetry. The HOMO and LUMO levels for PffBT4T-2OD, as indicated in literature [10], are also shown. 
The DFT computed HOMO and LUMO energies show a moderate agreement with the experimental values, Table 2. The LUMO energies show the best agreement, with differences up to 0.17 and $0.28 \mathrm{eV}$ for 70C and 70D respectively. For $C_{70}, \alpha 1$ and $\alpha 2$ diastereoisomers generally yield very similar frontier orbital energies with the exception of $\alpha 1-70 \mathrm{D}$ and $\alpha 2-70 \mathrm{D}$ HOMOs which differ by $0.08 \mathrm{eV}$. Also, the $\beta 1$ and $\beta 2 \mathrm{HOMO}$ and LUMO energies are very similar. Remarkably, when $\alpha$ and $\beta C_{70}$ isomers are systematically compared, HOMOs show lower energies, while LUMOs show higher energies. Thus, all $\alpha$ isomers have larger HOMO-LUMO gaps than $\beta$ isomers. Figure 3 shows the electron density for both frontier orbitals for all molecules. The HOMO orbitals are localized on the carbazole moiety for 60D and 70D structures. In all the other cases, the HOMO electron sit predominantly on the fullerene part, although for some systems-namely 60A, $\alpha-70 \mathrm{~A}, \alpha-70 \mathrm{~B}$, and $\beta 2-70 \mathrm{~B}$ - some density is also found on the functional groups. Interestingly, the LUMO orbitals, associated with the capacity of these molecules to act as electron acceptors, reside on the fullerene for all structures.

Table 2. Experimental and computed HOMO and LUMO energies at the PBE-def2-TZVP/PBEh-3c level. All values in $\mathrm{eV}$.

\begin{tabular}{|c|c|c|c|c|c|c|c|c|c|c|}
\hline & \multicolumn{5}{|c|}{ HOMO } & \multicolumn{5}{|c|}{ LUMO } \\
\hline & Exp. & $\alpha 1$ & $\alpha 2$ & $\beta 1$ & $\beta 2$ & Exp. & $\alpha 1$ & $\alpha 2$ & $\beta 1$ & $\beta 2$ \\
\hline $\mathrm{C}_{60}$ & & -5.80 & & & & & -4.10 & & & \\
\hline $\mathrm{C}_{70}$ & & -5.80 & & & & & -4.03 & & & \\
\hline $\mathrm{PC}_{61} \mathrm{BM}$ & -5.97 & -5.47 & & & & -3.89 & -3.94 & & & \\
\hline $\mathrm{PC}_{71} \mathrm{BM}$ & -5.87 & -5.52 & & -5.44 & & -3.89 & -3.85 & & -3.87 & \\
\hline $60 \mathrm{~A}$ & -5.75 & -5.40 & & & & -3.87 & -3.90 & & & \\
\hline $60 B$ & -5.72 & -5.36 & & & & -3.86 & -3.88 & & & \\
\hline $60 C$ & -5.82 & -5.60 & & & & -3.91 & -4.06 & & & \\
\hline $60 \mathrm{D}$ & -5.56 & -5.09 & & & & -3.97 & -3.84 & & & \\
\hline $70 \mathrm{~A}$ & -5.68 & -5.47 & -5.47 & -5.40 & -5.38 & -3.86 & -3.79 & -3.79 & -3.84 & -3.83 \\
\hline $70 B$ & -5.66 & -5.43 & -5.42 & -5.37 & -5.35 & -3.86 & -3.77 & -3.77 & -3.82 & -3.83 \\
\hline $70 \mathrm{C}$ & -5.74 & -5.69 & -5.69 & -5.61 & -5.60 & -3.89 & -4.01 & -4.00 & -4.06 & -4.04 \\
\hline $70 \mathrm{D}$ & -5.50 & -5.06 & -5.05 & -5.04 & -5.12 & -4.03 & -3.76 & -3.75 & -3.80 & -3.79 \\
\hline
\end{tabular}

The UV-vis absorption spectra recorded between 300 and $800 \mathrm{~nm}$ for the four $\mathrm{C}_{60}$ derivatives and the four $\mathrm{C}_{70}$ derivatives in $o$-DCB are shown in Figure S26. The $\mathrm{C}_{70}$ derivatives have a larger photo-absorption profile in the visible region. The absorption bands of the $\mathrm{C}_{60}$ derivatives are similar and the same happens with the absorption bands of the $C_{70}$ derivatives. In agreement with the literature $[43,46,47]$, the $\mathrm{C}_{60}$ derivatives display a large peak at $\sim 330 \mathrm{~nm}$, a small peak at $\sim 430 \mathrm{~nm}$ and a very weak absorption peak $700 \mathrm{~nm}$.

Figure 4 shows the UV-vis spectra of the blends and pure polymer, normalized to the intensity of their 0-1 transition peak at $\sim 700 \mathrm{~nm}$. As expected, considering the absorption spectra of the individual fullerenes shown in Figure $\mathrm{S} 26$, the $\mathrm{BHJs}$ with $\mathrm{C}_{70}$-fulleropyrrolidines exhibit a stronger light absorption in the range $400-700 \mathrm{~nm}$ than the corresponding $\mathrm{BHJs}$ with $\mathrm{C}_{60}$-fulleropyrrolidines.

Figure 5 a represents the standard architecture ITO/PEDOT:PSS/BHJ/Ca/Al of the devices considered in the present work. The current density-voltage $(\mathrm{J}-\mathrm{V})$ curves of devices processed with the eight fulleropyrrolidines, as well as a $\mathrm{PC}_{71} \mathrm{BM}$-based control device, are shown in Figure $5 \mathrm{~b}$. The corresponding figures of merit are shown in Figure $5 \mathrm{c}$ and in Table 3. 


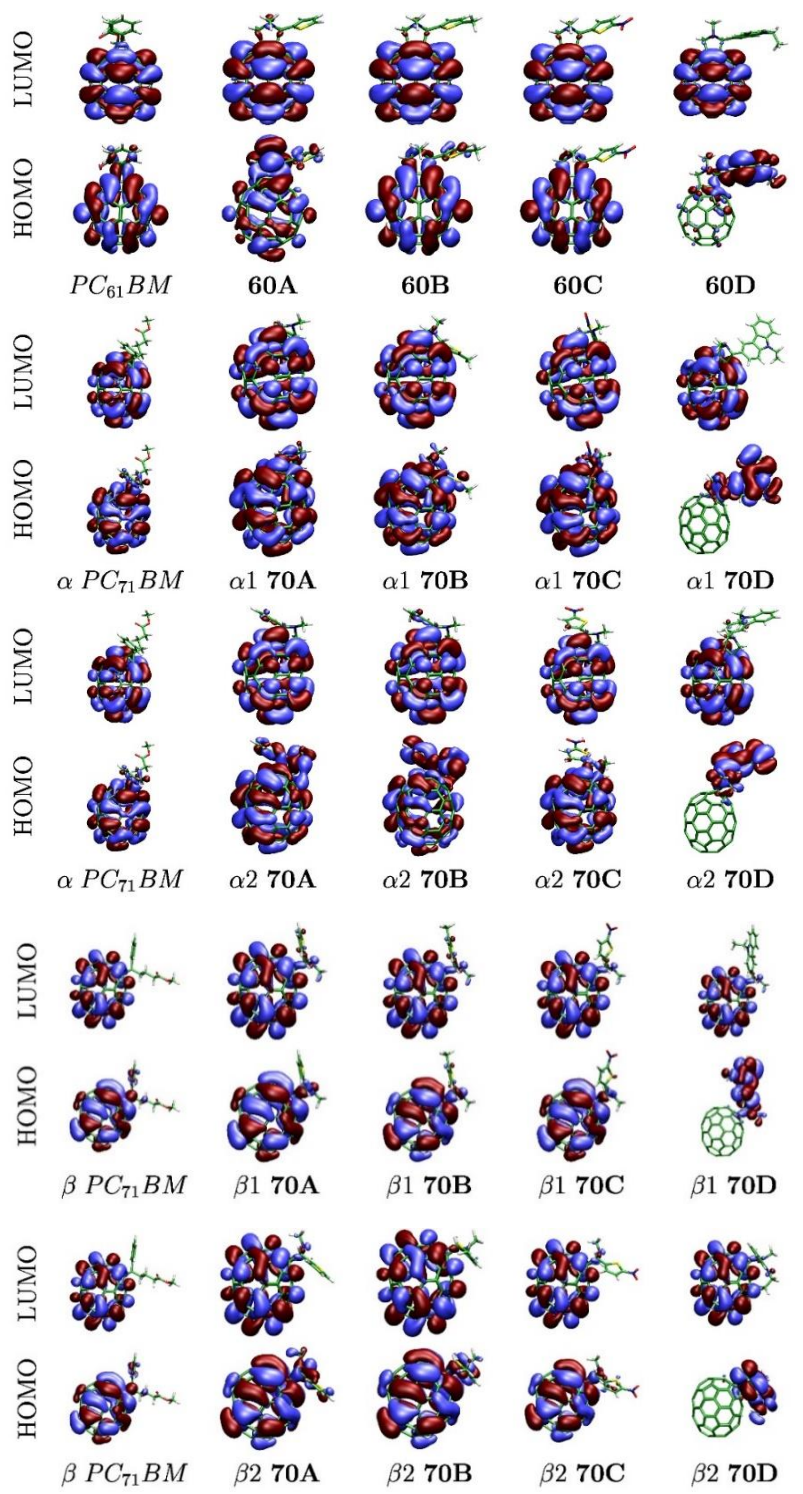

Figure 3. Frontier orbitals of pristine and functionalized $\mathrm{C}_{60}$ and $\mathrm{C}_{70}$ molecules.
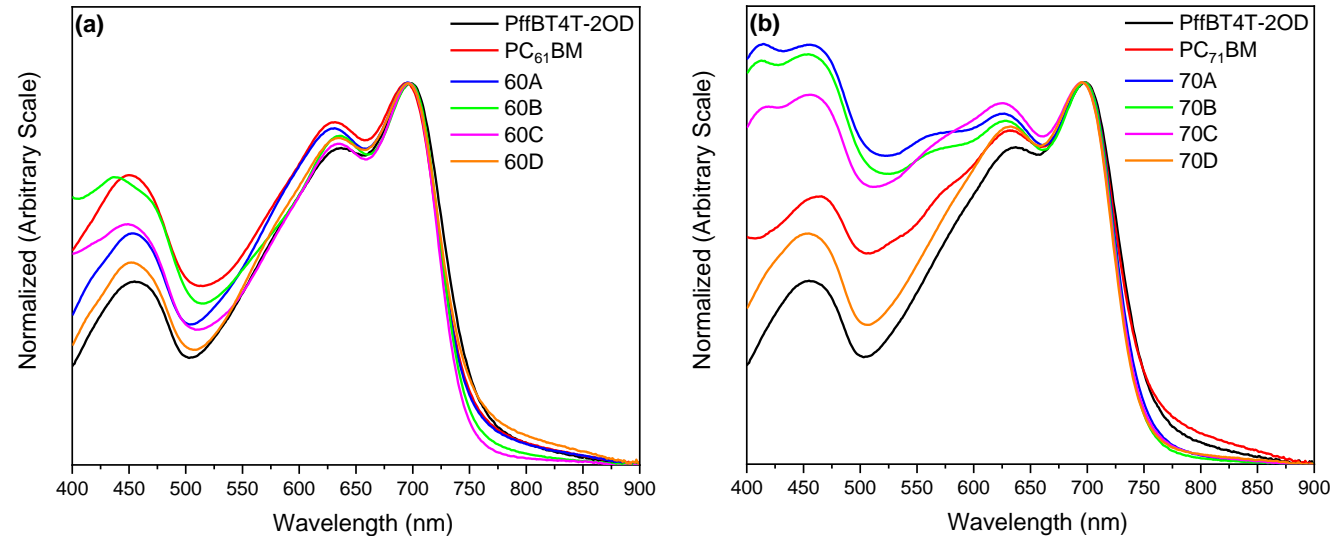

Figure 4. UV-vis spectra of a pristine PffBT4T-2OD film and of PffBT4T-2OD:fullerene blend films with: (a) $\mathrm{C}_{60}$-fullerenes and (b) $\mathrm{C}_{70}$-fullerenes. All spectra are normalized to the intensity of the polymer 0-1 transition peak at $\sim 700 \mathrm{~nm}$. 


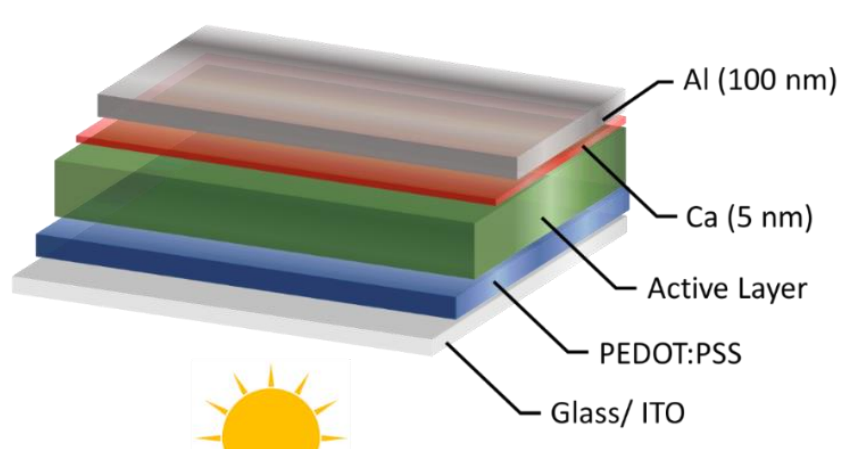

(a)

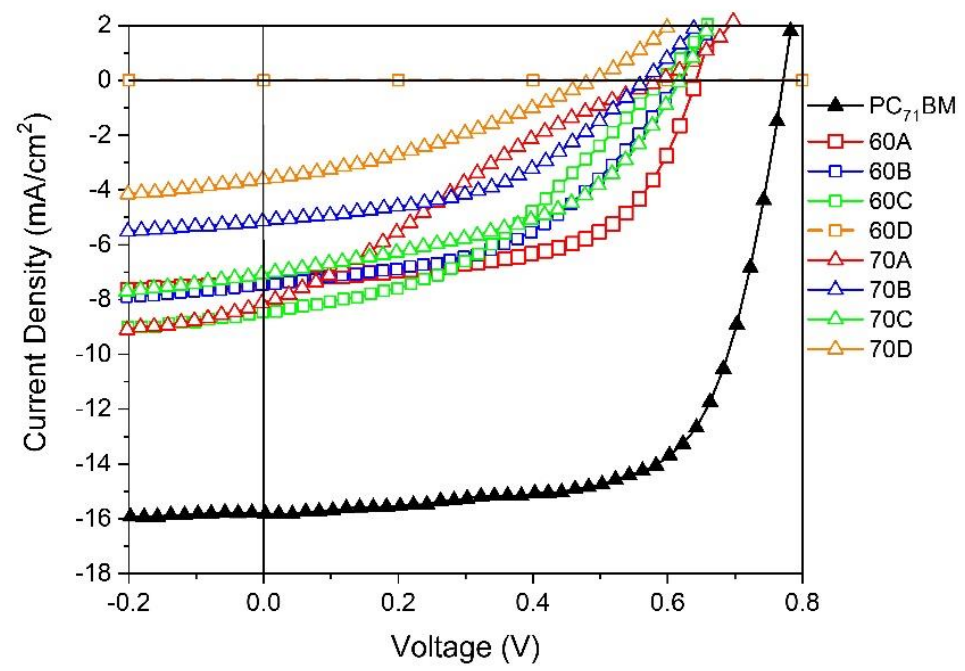

(b)
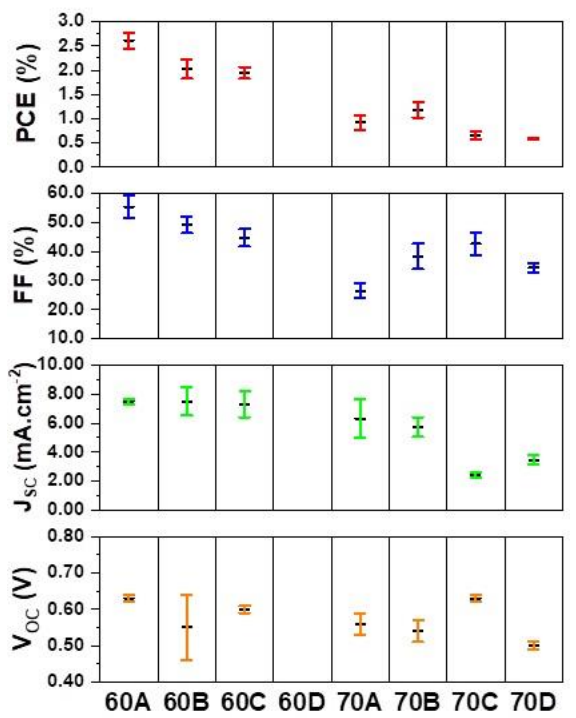

(c)

Figure 5. (a) A schematic of the standard structure of the devices; (b) Representative J-V curves for PffBT4T-2OD based devices with the $\mathrm{PC}_{71} \mathrm{BM}$ standard and with the eight fulleropyrrolidine acceptors 60A-60D and 70A-70D; (c) Overall device metrics for the eight different PffBT4T-2OD:fulleropyrrolidine based devices. 
Table 3. Device metrics for cells with different acceptors, showing the peak and (average of 8 devices) $P C E$ values.

\begin{tabular}{ccccc}
\hline PffBT4T-2OD & PCE (\%) & $\mathbf{V}_{\text {OC }}(\mathbf{V})$ & FF $(\%)$ & $\mathbf{J}_{\mathbf{s c}}\left(\mathbf{m A} / \mathbf{c m}^{\mathbf{2}}\right)$ \\
\hline PC $_{\mathbf{7 1}} \mathbf{B M}$ & $8.41(8.19 \pm 0.24)$ & $0.72(0.74 \pm 0.02)$ & $71.2(69.8 \pm 1.8)$ & $16.41(15.87 \pm 0.40)$ \\
\hline 60A & $2.78(2.61 \pm 0.16)$ & $0.64(0.63 \pm 0.01)$ & $58.7(55.3 \pm 3.9)$ & $7.36(7.48 \pm 0.15)$ \\
60B & $2.20(2.02 \pm 0.20)$ & $0.62(0.55 \pm 0.09)$ & $47.9(49.2 \pm 2.9)$ & $7.46(7.51 \pm 0.98)$ \\
60C & $2.04(1.94 \pm 0.12)$ & $0.59(0.60 \pm 0.01)$ & $40.7(44.8 \pm 3.0)$ & $8.46(7.30 \pm 0.90)$ \\
60D & $(0.07)$ & $(1.09)$ & $(45.6)$ & $(0.15)$ \\
\hline 70A & $1.15(0.92 \pm 0.15)$ & $0.59(0.56 \pm 0.03)$ & $24.2(26.4 \pm 2.5)$ & $8.08(6.32 \pm 1.30)$ \\
70B & $1.33(1.18 \pm 0.16)$ & $0.57(0.54 \pm 0.03)$ & $45.9(38.4 \pm 4.4)$ & $5.14(5.74 \pm 0.68)$ \\
70C & $0.75(0.65 \pm 0.08)$ & $0.62(0.63 \pm 0.01)$ & $47.5(42.6 \pm 4.0)$ & $2.52(2.43 \pm 0.16)$ \\
70D & $0.60(0.59 \pm 0.02)$ & $0.49(0.50 \pm 0.01)$ & $34.2(34.4 \pm 1.6)$ & $3.61(3.46 \pm 0.34)$ \\
\hline
\end{tabular}

As it is evident from Figure $5 b, c$ and Table 3 , all the fulleropyrrolidines originated devices with photovoltaic performances lower than reference devices based on $\mathrm{PC}_{71} \mathrm{BM}$. All the J-V curves of devices with fulleropyrrolidine acceptors show some space charge limited current (SCLC) effects, and interestingly devices based on 70A display a characteristic S-shaped similar to S-shaped J-V curves that have been previously reported in fulleropyrrolidine-based OPVs [43]. We note that previous work has often reported novel fullerenes that despite displaying more favorable LUMO levels than $\mathrm{PC}_{61} \mathrm{BM}$ and $\mathrm{PC}_{71} \mathrm{BM}$, gave rise to OPV devices with considerable lower PCE [34,46,47,58-64] and also with simultaneously lower PCE and $V_{O C}[34,46,47,62-64]$ than reference devices based on $\mathrm{PC}_{61} \mathrm{BM}$ and $\mathrm{PC}_{71} \mathrm{BM}$. In the present work, among our fulleropyrrolidine-based devices the best efficiencies $(\eta)$ are achieved by devices with the $\mathrm{C}_{60}$ derivatives $60 \mathrm{~A}(2.78 \%), 60 \mathrm{~B}(2.20 \%)$, and $60 \mathrm{C}(2.04 \%)$. These results show that a higher efficiency is obtained when the thiophene moiety does not contain any substituent in the remaining alpha position and the efficiency tends to decrease when this position is substituted with electron withdrawing substituents. It is also evident from Figure $5 \mathrm{c}$ and Table 3 that, in general, the $\mathrm{C}_{60}$ derivatives originate higher performing devices than the $\mathrm{C}_{70}$ derivatives, even though the latter have broader light absorption in the visible region as depicted in Figure 4 and Figure S26. The only exception occurs in compounds 60D and 70D, where 60D originates no efficiency and 70D originates an efficiency of $0.60 \%$. However, this exception is most likely associated with the solubility differences observed between 60D (low solubility) and 70D (more soluble) as the use of derivatives with a higher solubility tends to facilitate the process of thin film formation and dispersion in the $\mathrm{BHJ}$, therefore increasing the efficiency of the devices. $C_{70}$-based devices exhibit in general lower efficiency than $\mathrm{C}_{60}$-based devices, and in our opinion this is most probably due to the structural disorder (as shown in Table 1) and to the energetic disorder (as shown in Table 2) introduced in these systems by the presence of several $C_{70}$-fulleropyrrolidine isomers. In fact, as our DFT calculations (Table 2) show, different isomers of $\mathrm{C}_{70}$-fulleropyrrolidine have systematically different electronic properties. To further support these ideas, we note that for example, according to Umeyama et al. [65], in the particular case of the $\mathrm{PC}_{71} \mathrm{BM}$ mixture of isomers, the $\beta 1$-isomer present in the mixture of four isomers $(\alpha 1, \alpha 2, \beta 1$, and $\beta 2)$ does not contribute to the efficiency of the mixture.

The experimental J-V data was fitted, using genetic algorithms, to the OPV equivalent circuit [66]. The most relevant simulated J-V curves are displayed in Figure 6 and the full simulated data is presented in Table 4, namely the simulated values of $J_{p h}, R_{s}$ and $R_{p}$. Analysis of our data shows that there is no obvious relationship between the $V_{O C}$ values obtained and the $E_{L U M O}^{A}-E_{H O M O}^{D}$ energy level differences, as determined by cyclic voltammetry, although for samples 60A and 60B some trend was observed (as previous indicated and expected). This means that locally defined energy levels, arising from structural defects and/or inhomogeneous film formation, need to be taken into consideration. In fact, as previous work has shown, energetic disorder at D:A interphase can contribute for changing significantly the $V_{O C}$ values and this should be also occurring in the present work. The equivalent circuit $R_{p}$ (modelling physical electrical carrier's loss) helps, in some way, to support 
this hypothesis: higher $R_{p}$ corresponds in general to effectively higher $\eta$. Moreover, and besides these factors influencing $V_{O C}$, a decrease of $\mathrm{R}_{\mathrm{p}}$ usually leads to a decrease of $V_{O C}$ (equivalent circuit) and in general this behavior is observed, namely with samples $60 \mathrm{~A}, 60 \mathrm{~B}$, and $60 \mathrm{C}$ and with samples 70B, 70C, and 70D. However, we must take into account that we are comparing different samples (structure, LUMO/HOMO levels, and solubility) and therefore specific considerations for each of them should be also considered.
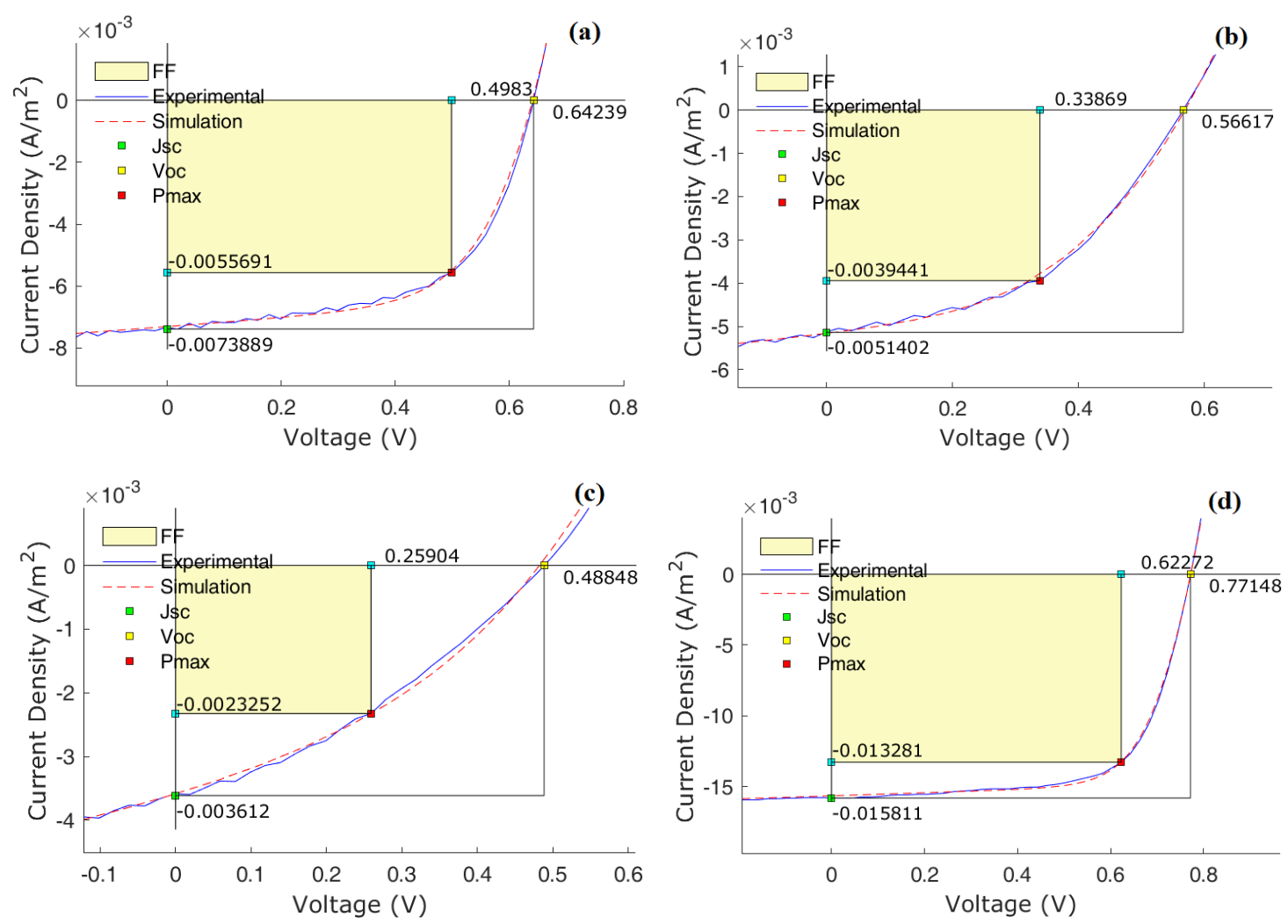

Figure 6. Experimental (solid lines) and simulated (dashed lines) J-V curves for OPVs based in donors (a) 60A, (b) 60C, (c) 70C, and (d) $\mathrm{PC}_{71} \mathrm{BM}$.

Table 4. Generated photocurrent $\left(J_{p h}\right)$ and parallel $\left(\mathrm{R}_{\mathrm{p}}\right)$ and series resistances $\left(\mathrm{R}_{\mathrm{s}}\right)$ determined by fitting the equivalent circuit to the experimental data.

\begin{tabular}{cccc}
\hline & $J_{p h}\left(\mathbf{m A} / \mathbf{c m}^{2}\right)$ & $\mathbf{R}_{\mathbf{s}}(\Omega)$ & $\mathbf{R}_{\mathbf{p}}(\Omega)$ \\
\hline $\mathbf{P C}_{\mathbf{7 1}} \mathbf{B M}$ & 16.41 & 159 & $9.72 \times 10^{4}$ \\
\hline 60A & 7.36 & 225 & $3.43 \times 10^{4}$ \\
60B & 7.65 & 633 & $2.40 \times 10^{4}$ \\
60C & 8.86 & 1157 & $1.39 \times 10^{4}$ \\
60D & $(0.15)$ & $(6032)$ & $\left(9.72 \times 10^{4}\right)$ \\
\hline $70 \mathrm{~A}$ & 8.57 & 1721 & $0.57 \times 10^{4}$ \\
$70 \mathrm{~B}$ & 5.33 & 1235 & $2.14 \times 10^{4}$ \\
$70 \mathrm{C}$ & 2.53 & 619 & $2.99 \times 10^{4}$ \\
$70 \mathrm{D}$ & 3.80 & 1644 & $1.41 \times 10^{4}$ \\
\hline
\end{tabular}

The series resistance $R_{S}$ - considering the usual high fluctuation of this parameter-exhibits for the $C_{60}$ series an expected relationship with $\eta$. An opposite relationship between $R_{s}$ and $R_{p}$ is observed in our samples, for $\mathrm{C}_{60}$ series (except 60D that we will discuss later): increasing the first (higher electrode/bulk resistance), the other decreases (higher electrical loss) which results in a loss of efficiency. However, it is interesting to note that $J_{S C}$ increases regardless the increase of $R_{s}$ and the decrease of $R_{p}$ 
(samples 60A, 60B, and 60C) suggesting a clear issue with the BHJ morphology and phase separation. On the other hand, for the $C_{70}$ samples two situations are of special interest: samples 70A and 70C. For the former, a high $R_{s}$ together with very low $R_{p}$ suggests an $I-V$ behavior departing from the typical electrical circuit model and this is confirmed by the strong SCLC influence in the J-V curve (although a surprisingly high $J_{S C}$ ) that markedly decreases the fill factor (FF). For the later and despite the moderately high $R_{p}$ and low $R_{s}$ values, the results are far from what we would a priori expect, even more having a favorable LUMO level. Clearly, a low $J_{S C}$ is a problem and considering that the light absorption of the blend with this donor displays an average behavior, we conclude that the energetic disorder should have a relevant influence in the OPVs made with this fullerene.

As a final evidence supporting the impact of the BHJ morphology on the macroscopic device behavior, we can observe that, as all the figures of merit of the OPVs degrade, the J-V curve clearly becomes an overlap of a diode characteristic curve with the expected curve from a charge transport under space charge (SCLC) conditions. Moreover, a simple comparison between $J_{S C}$ and $J_{p h}$ (estimated from the simulations and corresponding to the pure generated electrical carriers-power source in the equivalent electrical circuit) shows noticeable loss during the transport process. According to this, a degradation of the ideal equivalent electrical circuit behavior, should imply a decrease of the FF (observed in general) with further loss of efficiency. As all the active layers were deposited following the same procedure, it can be assumed that the different fulleropyrrolidine acceptors originate morphologically different films with significant influence in the electrical charge transport.

Notwithstanding the very low efficiency of the 60D-based devices, the discussion of their device metrics is interesting. In fact, OPVs made with the fulleropyrrolidine 60D have nearly zero efficiency $(<0.1 \%)$ mainly due to a nearly zero $J_{S C}$. Even though such extremely low PCE values, a suitable fit to the electrical equivalent circuit could be performed, showing that a very high $R_{s}$ is present (over 6 $\mathrm{K} \Omega$ ). Nevertheless, an optimal high value of $\mathrm{R}_{\mathrm{p}}$ is achieved, indicating that the loss in electrical carrier transport is low. Moreover, a moderate FF is obtained. However, the high $V_{O C}$ is typical of a 'single layer' OPV, i.e., just one material (donor or acceptor) is contributing to the electrical charge generation and transport. Considering that 70D-based devices also exhibit the worst efficiency among the $\mathrm{C}_{70}$ derivatives, it is clear that the carbazole substituent must originate a marked morphology degradation resulting in poorer D:A interfaces. This is most likely due to the lower solubility that the carbazole moiety imparts to the corresponding fulleropyrrolidine in organic solvents, and which should also reflect itself in a much less favorable polymer-fullerene interaction $[67,68]$.

We have performed AFM analysis, in tapping mode, of the surface morphology of the different BHJ films, and representative height images are shown in Figure 7, together with the associated values of root mean square $(\mathrm{rms})$ roughness inside brackets. The corresponding phase images are shown in Figure S27. However, when trying to correlate the surface morphologies with the device efficiencies the results are inconclusive as no clear correlation between the film morphologies and the OPV performances can be observed. For example, even though films $60 \mathrm{~A}$ and $60 \mathrm{C}$ present respectively the higher $(16.1 \mathrm{~nm})$ and lower $(2.1 \mathrm{~nm})$ values of $r m s$ roughness among all the eight devices, their corresponding device PCEs are very similar (maximum values of $2.78 \%$ and $2.04 \%$, respectively) and both are considerably higher than any of the 70A-70D based devices. These observations are not surprising considering that AFM only analyses the surface morphology of the films and this can be very different from the bulk morphology. A detailed morphological characterization of these films would require, besides the measurement of the size of phase domains, the measurement of the degree of purity and the degree of orientation (crystallinity) inside those phase domains and this would only be possible through the use of some hardly accessible techniques such as small angle neutron scattering (SANS) [11,69], neutron reflectivity [70], resonant soft X-ray scattering (RSoXS) [71], and grazing-incidence wide-angle X-ray scattering (GIWAXS) [72] and was beyond the scope of this work. 
60A $(16.1 \mathrm{~nm})$

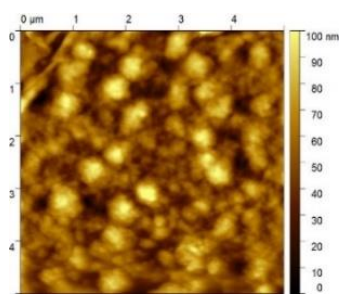

$70 \mathrm{~A}(3.6 \mathrm{~nm})$

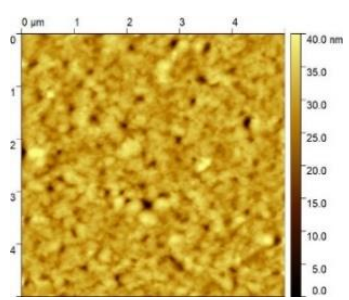

60B $(2.9 \mathrm{~nm})$

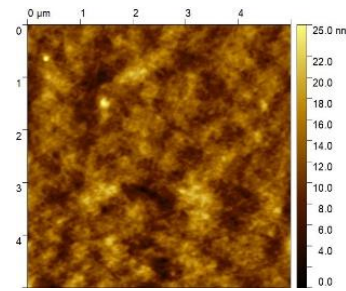

$70 \mathrm{~B}(3.6 \mathrm{~nm})$

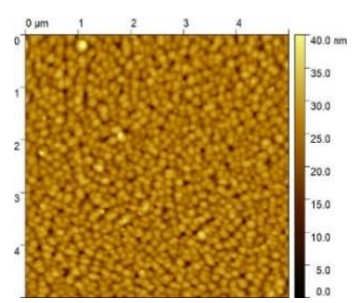

$60 \mathrm{C}(2.1 \mathrm{~nm})$

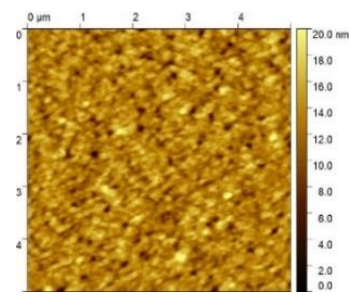

$70 \mathrm{C}(5.2 \mathrm{~nm})$

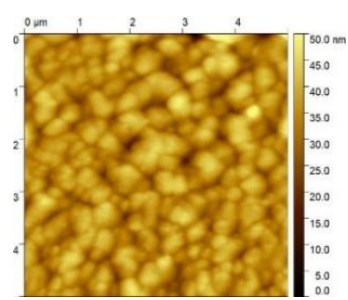

60D $(6.0 \mathrm{~nm})$

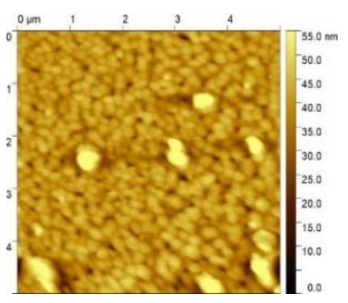

$70 \mathrm{D}(5.3 \mathrm{~nm})$

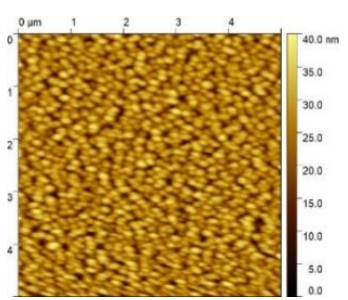

Figure 7. Morphological AFM images of BHJ films with different acceptors.

We note that the fullerene functionalization besides changing the HOMO/LUMO levels also affects several other properties with direct impact on the corresponding device efficiency. Different functionalization of the $\mathrm{C}_{60}$ and $\mathrm{C}_{70}$ cages, can modify dramatically their solid-state packing and crystallization properties and the electronic coupling between adjacent fullerenes, causing a significant change in their local electron mobility [73]. Furthermore, they can also modify the compatibility between the polymer and the fullerene and as a result the level of fullerene dispersion in the polymer matrix $[67,68,74]$. Consequently, several other parameters can be affected including the electron mobility of the fullerene phase in the BHJ $[19,75]$ and the LUMO level of the fullerene. Regarding this latter issue, for example Durrant et al. [76] have shown that $\mathrm{PC}_{61} \mathrm{BM}$ aggregation in the $\mathrm{BHJ}$ lowers systematically its LUMO level and variations in the film morphology can change the device $\mathrm{V}_{\mathrm{OC}}$ by up $\sim 0.2 \mathrm{~V}$ [77]. Piersimoni et al. [78] also demonstrated that fullerene crystallization reduces the energy of the charge transfer state $\left(E_{\mathrm{CT}}\right)$ and this causes a reduction in $V_{O C}$.

Finally, we refer to a 2017 study, by Karakawa et al. [79] of OPV devices using PEDOT: PSS as hole transport layer (HTL) and an active layer with $N$-alkyl-fulleropyrrolidine acceptors. These authors have identified an interfacial reaction between the basic $N$-alkyl-fulleropyrrolidine acceptors and the acidic PEDOT:PSS that affects the OPV performance. Interestingly, fulleropyrrolidines have been investigated as electron acceptors in OPVs for more than a decade, and although several works have published device data on inverted devices without PEDOT:PSS, the reason for that choice of device architecture was never mentioned before the work by Karakawa et al. This is an interesting topic that we will address with great detail in a future publication, by testing these same fullerenes in PEDOT:PSS-free devices with inverted architectures. For now, however, we believe from our data that the electrical transport, due to non-ideal D:A interphase separation, should be the main explanation for the obtained results.

\section{Conclusions}

We have demonstrated a simple approach for the chemical modification of N-methyl -fulleropyrrolidine acceptors that can be extended to thiophene and carbazole based moieties. However, OPV devices based on these novel fullerene acceptors performed worse than $\mathrm{PC}_{71} \mathrm{BM}$-based reference devices. Despite these lower performances obtained, our results confirm the critical dependence of the figures of merit of devices on the chemical structures of the fullerene derivative acceptors. As a main conclusion, it seems to be clear that the structural and energetic heterogeneity present in the isomer 
mixture of $\mathrm{C}_{70}$-fulleropyrrolidines is detrimental to device performance and this emphasizes the need to develop regioselective synthetic pathways.

Supplementary Materials: The following are available online at http://www.mdpi.com/1996-1944/13/6/1267/s1, Table S1. HOMO and LUMO levels for all materials as calculated from cyclic voltammetry; Figure S1 to S24: ${ }^{1} \mathrm{H}$ $\mathrm{NMR},{ }^{13} \mathrm{C} \mathrm{NMR}$, and HSQC spectra of derivatives $60 \mathrm{~A}$ to $60 \mathrm{D}$ and 70A to 70D; Figure S25. Structure of the four different $C_{70}$-fulleropyrrolidine isomers; Figure S26. UV-vis spectroscopy of the fullerenes in 1,2-dichlorobenzene (o-DCB); Figure S27. AFM phase images.

Author Contributions: G.B., J.C.V., and J.P.C.T. conceptualized the experimental and overall motivation for the work. H.G., F.F., and J.P.C.T. synthesized the novel fullerenes. K.S. and M.M.-F. performed the ab initio calculations. H.G., D.I., and A.M. conducted the cyclic voltammetry experiments. H.G. and L.P. prepared the OPV devices. H.G. and L.P. performed the electrical characterization and modelling of the devices. H.G. and F.F. performed the UV-vis characterization of pure fullerenes and bulk-heterojunctions. H.G. and C.M.P. performed the AFM analysis of the blend films. H.G., G.B., F.F., and L.P. wrote the initial draft of the manuscript with inputs from all the remaining authors, and subsequently the draft was revised by all the authors. J.C.V., A.M., G.B., J.P.C.T., and L.P. contributed for the funding of this work. All authors have read and agreed to the published version of the manuscript.

Funding: This work was financially supported by: Base Funding-UIDB/00511/2020 of the Laboratory for Process Engineering, Environment, Biotechnology and Energy-LEPABE-funded by national funds through the FCT/MCTES (PIDDAC). This work was partially funded within the scope of the project i3N, UIDB/50025/2020 \& UIDP/50025/2020, financed by national funds through the FCT/MEC. Thanks are also due to FCT/MEC for the financial support to QOPNA (FCT UID/QUI/00062/2019), CICECO-Aveiro Institute of Materials (UIDB/50011/2020 \& UIDP/50011/2020), CQE (FCT UIDB/00100/2020), and CIQUP (FCT UID/QUI/UI0081/2019) research units, through national funds and where applicable co-financed by the FEDER, within the PT2020 Partnership Agreement. H.G. thanks Fundação para a Ciência e a Tecnologia (FCT) for his PhD scholarship (SFRH/BD/103009/2014). The research contracts of F.F. (REF. -168-89-ARH/2018) is funded by national funds (OE), through FCT-Fundação para a Ciência e Tecnologia, I.P., in the scope of the framework contract foreseen in the numbers 4, 5, and 6 of article 23, of the Decree-Law 57/2016, of August 29, changed by Law 57/2017, of July 19. M.M.F. acknowledges also support from FCT under the project IF/00894/2015.

Acknowledgments: The authors acknowledge Mafalda Pereira (LEPABE, University of Porto) for help on the UV-vis measurements.

Conflicts of Interest: The authors declare no conflict of interest.

\section{References}

1. Inganas, O. Organic Photovoltaics over Three Decades. Adv. Mater. 2018, 30. [CrossRef] [PubMed]

2. Yu, J.S.; Zheng, Y.F.; Huang, J. Towards High Performance Organic Photovoltaic Cells: A Review of Recent Development in Organic Photovoltaics. Polymers 2014, 6, 2473-2509. [CrossRef]

3. Sondergaard, R.; Hosel, M.; Angmo, D.; Larsen-Olsen, T.T.; Krebs, F.C. Roll-to-roll fabrication of polymer solar cells. Mater. Today 2012, 15, 36-49. [CrossRef]

4. Xiao, Z.; Jia, X.; Ding, L.M. Ternary organic solar cells offer $14 \%$ power conversion efficiency. Sci. Bull. 2017, 62, 1562-1564. [CrossRef]

5. $\quad$ Li, S.S.; Ye, L.; Zhao, W.C.; Yan, H.P.; Yang, B.; Liu, D.L.; Li, W.N.; Ade, H.; Hou, J.H. A Wide Band Gap Polymer with a Deep Highest Occupied Molecular Orbital Level Enables 14.2\% Efficiency in Polymer Solar Cells. J. Am. Chem. Soc. 2018, 140, 7159-7167. [CrossRef] [PubMed]

6. Cui, Y.; Yao, H.F.; Zhang, J.Q.; Zhang, T.; Wang, Y.M.; Hong, L.; Xian, K.H.; Xu, B.W.; Zhang, S.Q.; Peng, J.; et al. Over $16 \%$ efficiency organic photovoltaic cells enabled by a chlorinated acceptor with increased open-circuit voltages. Nat. Commun. 2019, 10, 8. [CrossRef]

7. Meng, L.X.; Zhang, Y.M.; Wan, X.J.; Li, C.X.; Zhang, X.; Wang, Y.B.; Ke, X.; Xiao, Z.; Ding, L.M.; Xia, R.X.; et al. Organic and solution-processed tandem solar cells with 17.3\% efficiency. Science 2018, 361, 1094. [CrossRef]

8. Zhang, S.Q.; Ye, L.; Zhao, W.C.; Liu, D.L.; Yao, H.F.; Hou, J.H. Side Chain Selection for Designing Highly Efficient Photovoltaic Polymers with 2D-Conjugated Structure. Macromolecules 2014, 47, 4653-4659. [CrossRef]

9. Ma, W.; Yang, G.F.; Jiang, K.; Carpenter, J.H.; Wu, Y.; Meng, X.Y.; McAfee, T.; Zhao, J.B.; Zhu, C.H.; Wang, C.; et al. Influence of Processing Parameters and Molecular Weight on the Morphology and Properties of High-Performance PffBT4T-2OD:PC71BM Organic Solar Cells. Adv. Energy Mater. 2015, 5, 9. [CrossRef] 
10. Liu, Y.; Zhao, J.; Li, Z.; Mu, C.; Ma, W.; Hu, H.; Jiang, K.; Lin, H.; Ade, H.; Yan, H. Aggregation and morphology control enables multiple cases of high-efficiency polymer solar cells. Nat. Commun. 2014, 5, 5293. [CrossRef]

11. Zhang, Y.; Parnell, A.J.; Pontecchiani, F.; Cooper, J.F.K.; Thompson, R.L.; Jones, R.A.L.; King, S.M.; Lidzey, D.G.; Bernardo, G. Understanding and controlling morphology evolution via DIO plasticization in PffBT4T-2OD/PC71BM devices. Sci. Rep. 2017, 7, 44269. [CrossRef]

12. Zhang, Y.W.; Parnell, A.J.; Blaszczyk, O.; Musser, A.J.; Samuel, I.D.W.; Lidzey, D.G.; Bernardo, G. Effect of fullerene acceptor on the performance of solar cells based on PffBT4T-2OD. Phys. Chem. Chem. Phys. 2018, 20, 19023-19029. [CrossRef]

13. Zhang, W.; Hu, R.; Zeng, X.K.; Su, X.J.; Chen, Z.F.; Zou, X.S.; Peng, J.; Zhang, C.Y.; Yartsev, A. Effect of Post-Thermal Annealing on the Performance and Charge Photogeneration Dynamics of PffBT4T-2OD/PC71BM Solar Cells. Polymers 2019, 11, 408. [CrossRef]

14. Bi, Z.Z.; Naveed, H.B.; Mao, Y.M.; Yan, H.P.; Ma, W. Importance of Nucleation during Morphology Evolution of the Blade-Cast PffBT4T-2OD-Based Organic Solar Cells. Macromolecules 2018, 51, 6682-6691. [CrossRef]

15. Duan, L.P.; Yi, H.M.; Wang, Z.M.; Zhang, Y.; Haque, A.A.Z.; Sang, B.R.; Deng, R.; Uddin, A. Semitransparent organic solar cells based on PffBT4T-2OD with a thick active layer and near neutral colour perception for window applications. Sustain. Energy Fuels 2019, 3, 2456-2463. [CrossRef]

16. Ganesamoorthy, R.; Sathiyan, G.; Sakthivel, P. Review: Fullerene based acceptors for efficient bulk heterojunction organic solar cell applications. Sol. Energy Mater. Sol. Cells 2017, 161, 102-148. [CrossRef]

17. Gaspar, H.; Figueira, F.; Pereira, L.; Mendes, A.; Viana, C.J.; Bernardo, G. Recent Developments in the Optimization of the Bulk Heterojunction Morphology of Polymer: Fullerene Solar Cells. Materials 2018, 11, 2560. [CrossRef]

18. Zhang, C.H.; Mumyatov, A.; Langner, S.; Perea, J.D.; Kassar, T.; Min, J.; Ke, L.L.; Chen, H.W.; Gerasimov, K.L.; Anokhin, D.V.; et al. Overcoming the Thermal Instability of Efficient Polymer Solar Cells by Employing Novel Fullerene-Based Acceptors. Adv. Energy Mater. 2017, 7. [CrossRef]

19. Zhang, C.; Langner, S.; Mumyatov, A.V.; Anokhin, D.V.; Min, J.; Perea, J.D.; Gerasimov, K.L.; Osvet, A.; Ivanov, D.A.; Troshin, P.; et al. Understanding the correlation and balance between the miscibility and optoelectronic properties of polymer-fullerene solar cells. J. Mater. Chem. A 2017, 5, 17570-17579. [CrossRef]

20. Srivani, D.; Gupta, A.; Bhosale, S.V.; Ohkubo, K.; Bhosale, R.S.; Fukuzumi, S.; Bilic, A.; Jones, L.A.; Bhosale, S.V. A Triphenylamine-Naphthalenediimide-Fullerene Triad: Synthesis, Photoinduced Charge Separation and Solution-Processable Bulk Heterojunction Solar Cells. Asian J. Org. Chem. 2018, 7, 220-226. [CrossRef]

21. Landerer, D.; Sprau, C.; Baumann, D.; Pingel, P.; Leonhard, T.; Zimmermann, D.; Chochos, C.L.; Kruger, H.; Janietz, S.; Colsmann, A. Thermal Stabilization of the Bulk-Heterojunction Morphology in Polymer:Fullerene Solar Cells Using a Bisazide Cross-Linker. Solar Rrl 2019, 3. [CrossRef]

22. Wang, W.; Sun, R.; Guo, J.; Guo, J.; Min, J. An Oligothiophene-Fullerene Molecule with a Balanced Donor-Acceptor Backbone for High-Performance Single-Component Organic Solar Cells. Angew. Chem. Int. Ed. 2019, 58, 14556-14561. [CrossRef]

23. Sariciftci, N.S.; Smilowitz, L.; Heeger, A.J.; Wudl, F. Photoinduced electron-transfer from a conducting polymer to Buckminsterfullerene. Science 1992, 258, 1474-1476. [CrossRef]

24. Hummelen, J.C.; Knight, B.W.; Lepeq, F.; Wudl, F.; Yao, J.; Wilkins, C.L. Preparation and characterization of fulleroid and methanofullerene derivatives. J. Org. Chem. 1995, 60, 532-538. [CrossRef]

25. Yu, G.; Gao, J.; Hummelen, J.C.; Wudl, F.; Heeger, A.J. Polymer photovoltaic cells - Enhanced efficiencies via a network of internal donor-acceptor heterojunctions. Science 1995, 270, 1789-1791. [CrossRef]

26. Wienk, M.M.; Kroon, J.M.; Verhees, W.J.H.; Knol, J.; Hummelen, J.C.; van Hal, P.A.; Janssen, R.A.J. Efficient methano 70 fullerene/MDMO-PPV bulk heterojunction photovoltaic cells. Angew. Chem. Int. Ed. 2003, 42, 3371-3375. [CrossRef]

27. Williams, M.; Tummala, N.R.; Aziz, S.G.; Risko, C.; Bredas, J.L. Influence of Molecular Shape on Solid-State Packing in Disordered PC61BM and PC71BM Fullerenes. J. Phys. Chem. Lett. 2014, 5, 3427-3433. [CrossRef]

28. Zhang, F.J.; Zhuo, Z.L.; Zhang, J.; Wang, X.; Xu, X.W.; Wang, Z.X.; Xin, Y.S.; Wang, J.; Tang, W.H.; Xu, Z.; et al. Influence of PC60BM or PC70BM as electron acceptor on the performance of polymer solar cells. Sol. Energy Mater. Sol. Cells 2012, 97, 71-77. [CrossRef] 
29. Saianand, G.; Gopalan, A.-I.; Lee, J.-C.; Sathish, C.; Gopalakrishnan, K.; Unni, G.E.; Shanbhag, D.; Dasireddy, V.D.B.C.; Yi, J.; Xi, S.; et al. Mixed Copper/Copper-Oxide Anchored Mesoporous Fullerene Nanohybrids as Superior Electrocatalysts toward Oxygen Reduction Reaction. Small 2020, 16, 1903937. [CrossRef]

30. Bairi, P.; Tsuruoka, T.; Acharya, S.; Ji, Q.; Hill, J.P.; Ariga, K.; Yamauchi, Y.; Shrestha, L.K. Mesoporous fullerene C70 cubes with highly crystalline frameworks and unusually enhanced photoluminescence properties. Mater. Horiz. 2018, 5, 285-290. [CrossRef]

31. Benzigar, M.R.; Joseph, S.; Saianand, G.; Gopalan, A.-I.; Sarkar, S.; Srinivasan, S.; Park, D.-H.; Kim, S.; Talapaneni, S.N.; Ramadass, K.; et al. Highly ordered iron oxide-mesoporous fullerene nanocomposites for oxygen reduction reaction and supercapacitor applications. Microporous Mesoporous Mater. 2019, 285, 21-31. [CrossRef]

32. Li, C.-Z.; Yip, H.-L.; Jen, A.K.Y. Functional fullerenes for organic photovoltaics. J. Mater. Chem. 2012, 22, 4161-4177. [CrossRef]

33. Mi, D.; Kim, J.H.; Kim, H.U.; Xu, F.; Hwang, D.H. Fullerene Derivatives as Electron Acceptors for Organic Photovoltaic Cells. J. Nanosci. Nanotechnol. 2014, 14, 1064-1084. [CrossRef]

34. Kitaura, S.; Kurotobi, K.; Sato, M.; Takano, Y.; Umeyama, T.; Imahori, H. Effects of dihydronaphthyl-based 60 fullerene bisadduct regioisomers on polymer solar cell performance. Chem. Commun. 2012, 48, 8550-8552. [CrossRef]

35. He, Y.; Chen, H.-Y.; Hou, J.; Li, Y. Indene-C60 Bisadduct: A New Acceptor for High-Performance Polymer Solar Cells. J. Am. Chem. Soc. 2010, 132, 1377-1382. [CrossRef]

36. Deng, L.L.; Feng, J.; Sun, L.C.; Wang, S.; Xie, S.L.; Xie, S.Y.; Huang, R.B.; Zheng, L.S. Functionalized dihydronaphthyl-C-60 derivatives as acceptors for efficient polymer solar cells with tunable photovoltaic properties. Sol. Energy Mater. Sol. Cells 2012, 104, 113-120. [CrossRef]

37. Meng, X.Y.; Zhang, W.Q.; Tan, Z.A.; Du, C.; Li, C.H.; Bo, Z.S.; Li, Y.F.; Yang, X.L.; Zhen, M.M.; Jiang, F.; et al. Dihydronaphthyl-based 60 fullerene bisadducts for efficient and stable polymer solar cells. Chem. Commun. 2012, 48, 425-427. [CrossRef]

38. Lee, J.K.; Fujida, K.; Tsutsui, T.; Kim, M.R. Synthesis and photovoltaic properties of soluble fulleropyrrolidine derivatives for organic solar cells. Sol. Energy Mater. Sol. Cells 2007, 91, 892-896. [CrossRef]

39. Matsumoto, K.; Hashimoto, K.; Kamo, M.; Uetani, Y.; Hayase, S.; Kawatsura, M.; Itoh, T. Design of fulleropyrrolidine derivatives as an acceptor molecule in a thin layer organic solar cell. J. Mater. Chem. 2010, 20, 9226-9230. [CrossRef]

40. Mi, D.; Kim, H.U.; Kim, J.H.; Xu, F.; Jin, S.H.; Hwang, D.H. Synthesis of a soluble fulleropyrrolidine derivative for use as an electron acceptor in bulk-heterojunction polymer solar cells. Synth. Met. 2012, 162, 483-489. [CrossRef]

41. Saravanan, C.; Liu, C.-L.; Chang, Y.-M.; Lu, J.-D.; Hsieh, Y.-J.; Rwei, S.-P.; Wang, L. [60]Fulleropyrrolidines Bearing $\pi$-Conjugated Moiety for Polymer Solar Cells: Contribution of the Chromophoric Substituent on C60 to the Photocurrent. ACS Appl. Mater. 2012, 4, 6133-6141. [CrossRef]

42. Zhang, X.N.; Sun, L.; Zheng, W.; Bao, X.C.; Wang, N.; Wang, T.; Yang, R.Q. The preparation and properties of bulk-heterojunction organic solar cells with indole-containing fulleropyrrolidine derivatives as acceptors. Tetrahedron 2013, 69, 9544-9550. [CrossRef]

43. Karakawa, M.; Nagai, T.; Adachi, K.; Ie, Y.; Aso, Y. N-phenyl 60 fulleropyrrolidines: Alternative acceptor materials to PC61BM for high performance organic photovoltaic cells. J. Mater. Chem. A 2014, 2, 20889-20895. [CrossRef]

44. Kaunisto, K.M.; Subbaiyan, N.K.; Bikram, K.C.C.; Chukharev, V.I.; Hakola, H.M.; Vuorinen, T.K.; Manninen, V.M.; Tkachenko, N.V.; Lemmetyinen, H.J.; D'Souza, F. The effect of thiophene substituents of fulleropyrrolidine acceptors on the performance of inverted organic solar cells. Synth. Met. 2014, 195, 193-200. [CrossRef]

45. Pitliya, P.; Sun, Y.; Garza, J.C.; Liu, C.; Gong, X.; Karim, A.; Raghavan, D. Synthesis and characterization of novel fulleropyrrolidine in P3HT blended bulk heterojunction solar cells. Polymer 2014, 55, 1769-1781. [CrossRef]

46. Liang, Y.L.; Hao, Y.J.; Liu, X.D.; Feng, L.; Chen, M.Z.; Tang, Q.Q.; Chen, N.; Tang, M.L.; Sun, B.B.; Zhou, Y.; et al. Efficiency enhancement from 60 fulleropyrrolidine-based polymer solar cells through N-substitution manipulation. Carbon 2015, 92, 185-192. [CrossRef] 
47. Yamane, S.; Mizukado, J.; Takahashi, T.; Suzuki, Y.; Sakurai, M.; Hagihara, H.; Suda, H. Fulleropyrrolidine Derivatives with Benzophenone Moiety as Electron Acceptors in Thermally Stable Organic Photovoltaic Devices. Chem. Lett. 2015, 44, 527-529. [CrossRef]

48. Prato, M.; Maggini, M.; Giacometti, C.; Scorrano, G.; Sandona, G.; Farnia, G. Synthesis and electrochemical properties of substituted fulleropyrrolidines. Tetrahedron 1996, 52, 5221-5234. [CrossRef]

49. Grimme, S.; Brandenburg, J.G.; Bannwarth, C.; Hansen, A. Consistent structures and interactions by density functional theory with small atomic orbital basis sets. J. Chem. Phys. 2015, 143, 054107. [CrossRef]

50. Karton, A.; Waite, S.L.; Page, A.J. Performance of DFT for C60 Isomerization Energies: A Noticeable Exception to Jacob's Ladder. J. Phys. Chem. A 2019, 123, 257-266. [CrossRef]

51. Wang, H.; He, Y.; Li, Y.; Su, H. Photophysical and Electronic Properties of Five PCBM-like C60 Derivatives: Spectral and Quantum Chemical View. J. Phys. Chem. A 2012, 116, 255-262. [CrossRef]

52. Beu, T.A.; Onoe, J.; Hida, A. First-principles calculations of the electronic structure of one-dimensional C-60 polymers. Phys. Rev. B 2005, 72, 155416. [CrossRef]

53. Neese, F. The ORCA program system. Wiley Interdiscip. Rev. Comput. Mol. Sci. 2012, 2, 73-78. [CrossRef]

54. Bernardo, G.; Melle-Franco, M.; Washington, A.L.; Dalgliesh, R.M.; Li, F.; Mendes, A.; Parnell, S.R. Different agglomeration properties of PC61BM and PC71BM in photovoltaic inks-A spin-echo SANS study. Rsc Adv. 2020, 10, 4512-4520. [CrossRef]

55. Gaspar, H.; Figueira, F.; Strutyński, K.; Melle-Franco, M.; Ivanou, D.; Tomé, J.P.C.; Pereira, C.M.; Pereira, L.; Mendes, A.; Viana, J.C.; et al. PffBT4T-2OD Based Solar Cells with Aryl-Substituted N-Methyl-Fulleropyrrolidine Acceptors. Materials 2019, 12, 4100. [CrossRef]

56. Lu, L.Y.; Chen, W.; Xu, T.; Yu, L.P. High-performance ternary blend polymer solar cells involving both energy transfer and hole relay processes. Nat. Commun. 2015, 6. [CrossRef]

57. Pan, M.-A.; Lau, T.-K.; Tang, Y.; Wu, Y.-C.; Liu, T.; Li, K.; Chen, M.-C.; Lu, X.; Ma, W.; Zhan, C. 16.7\%-efficiency ternary blended organic photovoltaic cells with PCBM as the acceptor additive to increase the open-circuit voltage and phase purity. J. Mater. Chem. A 2019, 7, 20713-20722. [CrossRef]

58. He, Y.J.; Chen, H.Y.; Zhao, G.J.; Hou, J.H.; Li, Y.F. Biindene-C-60 adducts for the application as acceptor in polymer solar cells with higher open-circuit-voltage. Sol. Energy Mater. Sol. Cells 2011, 95, 899-903. [CrossRef]

59. Kim, H.U.; Mi, D.; Kim, J.H.; Park, J.B.; Yoon, S.C.; Yoon, U.C.; Hwang, D.H. Carbazole-containing fullerene derivatives for P3HT-based bulk-heterojunction solar cells. Sol. Energy Mater. Sol. Cells 2012, 105, 6-14. [CrossRef]

60. Tseng, N.-W.; Yu, Y.; Li, Y.; Zhao, J.; So, S.K.; Yan, H.; Ng, K.M. Isobenzofulvene-fullerene mono-adducts for organic photovoltaic applications. J. Mater. Chem. C 2015, 3, 977-980. [CrossRef]

61. Liu, G.X.; Cao, T.T.; Xia, Y.J.; Song, B.; Zhou, Y.; Chen, N.; Li, Y.F. Dihydrobenzofuran-C-60 bisadducts as electron acceptors in polymer solar cells: Effect of alkyl substituents. Synthetic Met. 2016, 215, 176-183. [CrossRef]

62. Nisic, F.; Colombo, A.; Dragonetti, C.; Cominetti, A.; Pellegrino, A.; Perin, N.; Po, R.; Tacca, A. Novel Terthiophene-Substituted Fullerene Derivatives as Easily Accessible Acceptor Molecules for Bulk-Heterojunction Polymer Solar Cells. Int. J. Photoenergy 2014. [CrossRef]

63. Choi, J.H.; Son, K.-I.; Kim, T.; Kim, K.; Ohkubo, K.; Fukuzumi, S. Thienyl-substituted methanofullerene derivatives for organic photovoltaic cells. J. Mater. Chem. 2010, 20, 475-482. [CrossRef]

64. Tao, R.; Umeyama, T.; Kurotobi, K.; Imahori, H. Effects of Alkyl Chain Length and Substituent Pattern of Fullerene Bis-Adducts on Film Structures and Photovoltaic Properties of Bulk Heterojunction Solar Cells. ACS Appl. Mater. Interfaces 2014, 6, 17313-17322. [CrossRef] [PubMed]

65. Umeyama, T.; Igarashi, K.; Sakamaki, D.; Seki, S.; Imahori, H. Unique cohesive nature of the $\beta 1$-isomer of [70]PCBM fullerene on structures and photovoltaic performances of bulk heterojunction films with PffBT4T-2OD polymers. Chem. Commun. 2018, 54, 405-408. [CrossRef]

66. Trindade, A.J.; Pereira, L. Bulk Heterojunction Organic Solar Cell Area-Dependent Parameter Fluctuation. Int. J. Photoenergy 2017, 10. [CrossRef]

67. Treat, N.D.; Varotto, A.; Takacs, C.J.; Batara, N.; Al-Hashimi, M.; Heeney, M.J.; Heeger, A.J.; Wudl, F.; Hawker, C.J.; Chabinyc, M.L. Polymer-Fullerene Miscibility: A Metric for Screening New Materials for High-Performance Organic Solar Cells. J. Am. Chem. Soc. 2012, 134, 15869-15879. [CrossRef] 
68. Bernardo, G.; Deb, N.; King, S.M.; Bucknall, D.G. Phase behavior of blends of PCBM with amorphous polymers with different aromaticity. J. Polym. Sci. Part B Polym. Phys. 2016, 54, 994-1001. [CrossRef]

69. Bernardo, G.; Gaspar, H.; Pérez, G.E.; Shackleford, A.S.D.; Parnell, A.J.; Bleuel, M.; Mendes, A.; King, S.M.; Parnell, S.R. Impact of 1,8-diiodooctane on the morphology of organic photovoltaic (OPV) devices-A Small Angle Neutron Scattering (SANS) study. Polym. Test. 2020, 82, 106305. [CrossRef]

70. Parnell, A.J.; Dunbar, A.D.F.; Pearson, A.J.; Staniec, P.A.; Dennison, A.J.C.; Hamamatsu, H.; Skoda, M.W.A.; Lidzey, D.G.; Jones, R.A.L. Depletion of PCBM at the Cathode Interface in P3HT/PCBM Thin Films as Quantified via Neutron Reflectivity Measurements. Adv. Mater. 2010, 22, 2444. [CrossRef]

71. Wu, Y.; Wang, Z.Y.; Meng, X.Y.; Ma, W. Morphology Analysis of Organic Solar Cells with Synchrotron Radiation Based Resonant Soft X-Ray Scattering. Prog. Chem. 2017, 29, 93-101. [CrossRef]

72. Muller-Buschbaum, P. The Active Layer Morphology of Organic Solar Cells Probed with Grazing Incidence Scattering Techniques. Adv. Mater. 2014, 26, 7692-7709. [CrossRef] [PubMed]

73. Ide, J.; Fazzi, D.; Casalegno, M.; Meille, S.V.; Raos, G. Electron transport in crystalline PCBM-like fullerene derivatives: A comparative computational study. J. Mater. Chem. C 2014, 2, 7313-7325. [CrossRef]

74. Bernardo, G.; Bucknal, D.G. Recent Progress in the Understanding and Manipulation of Morphology in Polymer: Fullerene Photovoltaic Cells. In Optoelectronics_Advanced Materials and Devices; Pyshkin, S.L., Ballato, J.M., Eds.; IntechOpen: Rijeka, Croatia, 2013; pp. 207-227.

75. Long, G.K.; Shi, R.; Zhou, Y.C.; Li, A.L.; Kan, B.; Wu, W.R.; Jeng, U.S.; Xu, T.; Yan, T.Y.; Zhang, M.T.; et al. Molecular Origin of Donor- and Acceptor-Rich Domain Formation in Bulk-Heterojunction Solar Cells with an Enhanced Charge Transport Efficiency. J. Phys. Chem. C 2017, 121, 5864-5870. [CrossRef]

76. Jamieson, F.C.; Domingo, E.B.; McCarthy-Ward, T.; Heeney, M.; Stingelin, N.; Durrant, J.R. Fullerene crystallisation as a key driver of charge separation in polymer/fullerene bulk heterojunction solar cells. Chem. Sci. 2012, 3, 485-492. [CrossRef]

77. Credgington, D.; Durrant, J.R. Insights from Transient Optoelectronic Analyses on the Open-Circuit Voltage of Organic Solar Cells. J. Phys. Chem. Lett. 2012, 3, 1465-1478. [CrossRef]

78. Piersimoni, F.; Chambon, S.; Vandewal, K.; Mens, R.; Boonen, T.; Gadisa, A.; Izquierdo, M.; Filippone, S.; Ruttens, B.; D'Haen, J.; et al. Influence of Fullerene Ordering on the Energy of the Charge-Transfer State and Open-Circuit Voltage in Polymer: Fullerene Solar Cells. J. Phys. Chem. 2011, 115, 10873-10880. [CrossRef]

79. Karakawa, M.; Nagai, T. Interfacial Reaction of Fulleropyrrolidines Affecting Organic Photovoltaic Performance. ACS Appl. Mater. Interfaces 2017, 9, 21338-21345. [CrossRef] 